\title{
is Research Square \\ Does It Pay to Offend? Short- and Long-term Responses to Offensive Ads
}

\author{
Enav Friedmann ( $\triangle$ Enavfrie@bgu.ac.il ) \\ Ben Gurion University \\ Eliran Solodoha \\ Ben Gurion University \\ Dorit Efrat Treister \\ Ben Gurion University
}

\section{Research Article}

Keywords: Offensive-stereotyping ads, consumer response, power approach, short and long term

Posted Date: August 10th, 2020

DOI: https://doi.org/10.21203/rs.3.rs-54289/v1

License: () (7) This work is licensed under a Creative Commons Attribution 4.0 International License. Read Full License 


\section{Abstract}

How does the use of offensive ads, especially those which insult low-power social groups, affect consumer response? Existing literature stresses the immediate negative consumer response to offensive ads, while practice shows continuing use of offensive ads by firms, creating a discrepancy between the literature and practice. In four studies (two in the field and two in the lab) we demonstrate a negative short-term response but positive long-term response to offensive ads in purchase intentions and brand choice, a phenomenon that we term the "time-offense paradox" (TOP). The effect is driven mainly by a larger positive increase in consumer response in the long term among members of low-power groups (compared to high-power groups). We call this the 'Trigger TOP effect'. In line with power-approach theory, we suggest and show that offensiveness influences brand choice via brand power and brand attraction (a two-path mediation). Our framework integrates the dimension of time into power-approach theory in the context of offensive ads.

\section{Introduction}

The use of ads that are offensive to segments of consumers are is generally assumed to alienate customers and lead to reduced consumer response (lowering purchase intentions and actual brand choice). This assumption is incongruent with the continued or even increasing use of such ads in marketing (European Advertising Standards Alliance 2017; Fam and Waller 2003; Huhmann and Mott-Stenerson 2008; Klimin and Tikhonov 2016; Prendergast, Ho, and Phau 2002). For example, the Snickers chocolate brand ran ads that were considered homophobic, sexist, or fat-shaming for years (Clark 2007; Wade 2014). The GoDaddy website builder firm has run ads that promote negative stereotypes about women (Calkins and Rucker 2016), and Goldstar beer has flaunted ads viewed as sexist in different forms since 2009 (Kyres 2016). In 2011, ads for Dove soap were criticized for positioning women of varying skin colors on a page so as to imply that a black woman would become lighter in complexion after using the product; and the same theme was repeated in 2017, despite complaints from consumers (Astor 2017). Other well-known brands that have used offensive ads in the last decade are Dunkin- Donuts, Bloomingdale's, Bud Light (Piedfort 2019), McDonald's, BurgerKing, KFC, Pot Noodle (Rahim, 2017), Flora, IKEA, Sprite, Quizno's, Reebok, Ford (Shandrow 2016), Dolce and Gabbana (Idiens 2018), PETA, Bacardi Breezer (Mertes 2019), Time Warner Cable, and the Dodge Charger (Lukyanova 2016). These are only few examples of the wide use of offensive ads.

Why do companies repeatedly use offensive ads? Presumably they do so because the ads work, in the sense of increasing sales. If so, how much of these sales derive from consumers who are members of the offended groups, and why do those consumers buy goods from the offending firms? In this research we explore these questions using a combination of field data and online experiments. We propose that the existing scholarly literature tends to examine the immediate consumer response to offensive ads, measured as attitudes or intentions, whereas actual purchases reflect a long-term consumer response. Our findings show that negative responses to offensive ads give way to a positive effect on consumer responses toward the brand over timewhat we call the "time-offense paradox" (TOP). Put simply, offensive ads repel consumers in the short term but attract them in the long term.

Our research contributes to the existing literature in several ways. First, we help explain the discrepancy between literature and practice by simulating real consumer behaviors, integrating the time dimension into 
power-approach theory (Keltner, Gruenfeld, and Anderson 2003), and examining the effects on brand choice (beyond purchase intentions). We demonstrate that offensive ads have a positive effect on consumer response (the TOP effect); and we show that this effect is especially evident among the low-power group (which triggers the TOP effect). Finally, we elucidate the underlying mechanism behind this long-term effect: the offensive ad conveys brand power which attracts low-power consumers to the brand, elevating brand choice.

From a theoretical perspective, our findings are aligned with power approach theory (Keltner et al., 2003) and with compensatory consumption theory (Mandel et al. 2017; Rucker and Galinsky 2008; Ward and Dahl 2014; Coleman, Williams and Morales, 2019). From a practical perspective we point to the need for greater consumer awareness of the mechanisms employed by brands and advertisers, and potentially for greater regulation.

In what follows, we first outline our conceptual framework. We then describe our four studies: two field studies (study 1 and study 4) and two lab studies (study 2 and study 3 ). The field studies and one lab study (study 3) examine ads definable as sexist, or offensive to women; the ad considered in study 2 is definable as racist, or offensive to blacks. We conclude with a general discussion, implications, and suggestions for future research.

\section{Conceptual Framework}

\section{Offensive Ads and Perceived Brand Power}

Controversial and offensive content in ads includes explicit sexual practices, racial prejudice, and messages that stereotypically portray members of different social groups (Waller 2004; Liu, Lamberton, Bettman and Fitzsimons, 2019). Offensive ads usually affront low-power groups who are subject to discrimination and/or negative stereotyping within society, such as women and members of black or minority ethnic groups (Magee and Galinsky 2008). Such ads have been conceptualized as coercive attempts to exercise social power (Wisse and Sleebos 2016). For example, Johnson, Neuendorf, and Skalski (2012) suggest that racial disparagement in ads is related to ethnic majority expressions of social power. Offensive ads lead to perceptions of a media environment characterized by prejudice and discrimination (Zeigler-Hill 2007) and microaggressions (Sue 2010).

A large category of offensive ads are those deemed to be sexist or demeaning to women (Furnham and Lay 2019). Such ads may belittle women by exaggerating sex-role stereotypes, which imply that women are less capable than men in certain spheres of life, or by using sexual innuendos to imply that women's role is to be sexual objects (Matthes et al. 2016; Sengupta and Dahl 2008). For example, a Sprite online ad campaign in 2016 briefly used slogans such as "She's seen more ceilings than Michelangelo" and "You're not popular, you're easy," until the company was forced to backtrack (Hall 2016). Another group often subject to offensive ads is racial minorities (Chan, Diehl, and Terluter 2007; Waller, Deshpande, and Zafer Erdogan 2013). For example, African-Americans are often represented in ads as aggressive, suggesting an ideology of white racial superiority (Cohen-Eliya and Hammer 2004; Ward 2004). In both cases, insults in ads from a member of 
a high-power group in society (but not a low-power group) are perceived as legitimate or convincing (Bond et al. 1985). Thus, the insult creates perception of power (Wisse and Sleebos 2016).

\section{Brand Power and Consumer Response}

Power is a desirable basic force in social relationships that influences human behavior (Fiske 1993). Individuals derive power, in part, from the groups to which they belong (Berger, Cohen, and Zelditch 1972). Thus, demographic segments (e.g., gender, race, age, class, etc.) vary in their social power (Ritzer and Stepinisky 2007).

Power-approach theory (Keltner et al. 2003) posits that power is perceived (either consciously or unconsciously) as desirable because it is associated with rewards and opportunities. Power reflects control over material, social, and psychological resources. Hence, powerful objects, people, or brands are attractive to others. Conversely, a lack of power is associated with increased threats and restricted opportunities, and people respond to low- power others with avoidance behaviors (Keltner et al., 2003).

Power-approach theory has not yet been applied in the context of offensive ads. Given that people do not generally make purchases immediately upon seeing an ad, the time dimension is relevant when examining consumer responses. This study therefore adds the time dimension to power-approach theory to examine consumers' response to offensive ads over time.

\section{Offensive Ads and Consumer Response}

Most research examining the effect of offensive ads has focused on the short-term effects of such ads on consumer responses. Findings show that offensive ads damage short-term brand sales, and create a negative company image (Ford, LaTour, and Honeycutt 1997; Prendergast et al. 2002; Rojas-Mendez, Davies, and Madran 2009; Van Hellemont and Van den Bulck 2012).

The immediate response to an offensive stimulus might include anxiety and stress, which can be characterized as a "fight or flight" response (Bracha, Williams, and Bracha 2004). A "fight" response is characterized by anger, especially among consumers who consider themselves part of the offended group (Yzerbyt et al. 2003). Angry consumers may engage in campaigns against the brand or the firm in the media and public discourse, for example by pressuring advertisers to withdraw the ad or calling for boycotts against the firm and its brands (Crosier and Zafer Erdogan 2001). Where regulations exist, consumers may complain to regulatory bodies (Waller et al. 2013). A "flight" response to offensive ads may manifest itself in lower purchase intentions, reduced sales, and damage to the firm's reputation and value (Chan et al. 2007; Madni, Abdul Hamid, and Mohd Rashid 2016; Rojas-Mendez et al. 2009; Van Hellemont and Van den Bulck 2012; Waller et al. 2013).

However, most studies of responses to offensive ads have been conducted over the short term, by examining purchase intentions immediately after consumers view an offensive ad. We suggest that over time, the effect of the insult recedes and gives way to attraction, based on the power represented by the ad. Thus, a study of 
brand choice over the long term comprises a more realistic simulation of real sales (Friedmann and Bruller 2018).

Based on the foregoing, we predict:

H1: Exposure to offensive ads will lead to a more positive consumer response to the brand over time, compared to the change when exposed to a control ad (TOP effect).

Power attracts everyone, but is known to especially attract low-power individuals. The approach to highpower brands in an effort to (re)gain power is known as compensatory consumption (Rucker and Galinsky 2008). Supporting this, low power individuals were found to be attracted to leader powerful brands (Beck, Rahinel and Bleier, 2020).

Thus, we predict a 'trigger TOP' effect for individuals with low power (blacks in study 2 and women in study 3):

H2: $\quad$ Group membership will moderate the relationship between time since exposure to offensive ads and consumer response. Specifically, exposure to offensive ads will create a stronger increase in consumer response over time among women and blacks compared to men and whites, respectively (the trigger TOP effect).

Taken together we expect:

H3: When brands use offensive ads, the influence of ads' offensiveness on brand choice is mediated by brand power and brand attraction, such that the more offensive the ad, the more it is perceived as powerful and attractive, and the more likely consumers are to choose that brand (three-path mediation model). This effect will be stronger among women compared to men.

\section{The Current Research}

We test our framework in two sets of studies. First, we conducted a two-part field study in the real-world using data relating to a well-known beer brand that frequently offends women in their advertising campaigns. Study $1 \mathrm{a}$ investigated the predicted TOP effect, and study $1 \mathrm{~b}$ investigated the predicted trigger TOP effect. In the second set of studies, we examined these effects experimentally. In study 2 we examined purchase intentions among white and black participants over the short and long terms (immediately and 10 days later, respectively). In study 3 we examined brand choice among male and female participants over four time points (baseline, immediately, 10 days, one month). Study 4 is a descriptive survey, focusing on the mechanism behind the long-term effect of offensive vs. non-offensive brands. A pretest ensured that (a) control ads were different from treatment ads in their perceived offensiveness and brand power, and that (b) low- and high-power groups (blacks vs. whites, females vs. males) indeed differ in social power. All studies were approved by the relevant university ethics committee. See table 1. 


\section{Table 1 Overview of Studies}




\begin{tabular}{|c|c|c|c|c|c|c|}
\hline Study & Context & $\begin{array}{l}\text { Final sample } \\
\text { size }\end{array}$ & $\begin{array}{l}\text { Attrition } \\
\text { between } \\
\text { measurements }\end{array}$ & Hypothesis & $\begin{array}{l}\text { Research } \\
\text { design }\end{array}$ & $\begin{array}{l}\text { Study } \\
\text { focus }\end{array}$ \\
\hline $\begin{array}{l}\text { Study 1a: } \\
\text { Field study } \\
\text { Overall } \\
\text { beer sales }\end{array}$ & $\begin{array}{l}\text { Relationship } \\
\text { between } \\
\text { perceived } \\
\text { offensiveness } \\
\text { of ads for a } \\
\text { well-known } \\
\text { beer brand } \\
\text { and sales } \\
\text { during the } \\
\text { month } \\
\text { following vs. } \\
\text { the month } \\
\text { preceding } \\
\text { each ad. }\end{array}$ & $\begin{array}{l}24 \text { judges } \\
\text { ( } 12 \text { men, } 12 \\
\text { women) } \\
\text { evaluated } 11 \\
\text { ads that ran } \\
\text { between } \\
2014 \text { and } \\
2017 \text {. }\end{array}$ & $\mathrm{N} / \mathrm{A}$ & $\begin{array}{l}\mathrm{H} 1 \\
\text { DV: actual } \\
\text { choice } \\
\text { (sales in } \\
\text { liters) }\end{array}$ & $\begin{array}{l}\text { A market } \\
\text { analysis of } \\
\text { beer sales } \\
\text { over the } \\
\text { month } \\
\text { following vs. } \\
\text { the month } \\
\text { preceding } \\
\text { offensive vs. } \\
\text { non-offensive } \\
\text { ads. }\end{array}$ & $\begin{array}{l}\text { TOP } \\
\text { effect } \\
\text { on } \\
\text { choice }\end{array}$ \\
\hline $\begin{array}{l}\text { Study } 1 b \text { : } \\
\text { Short } \\
\text { survey } \\
\text { Beer } \\
\text { choice by } \\
\text { gender }\end{array}$ & $\begin{array}{l}\text { Percentage of } \\
\text { women vs. } \\
\text { men } \\
\text { choosing the } \\
\text { offensive } \\
\text { beer brand } \\
\text { out of a local } \\
\text { and } \\
\text { international } \\
\text { choice set. }\end{array}$ & $\begin{array}{l}261 \\
\text { students (71 } \\
\text { men, } 190 \\
\text { women). }\end{array}$ & $\mathrm{N} / \mathrm{A}$ & $\begin{array}{l}\mathrm{H} 2 \\
\text { DV: } \\
\text { simulated } \\
\text { brand } \\
\text { choice }\end{array}$ & $\begin{array}{l}\text { Descriptive } \\
\text { survey }\end{array}$ & $\begin{array}{l}\text { Trigger } \\
\text { TOP } \\
\text { effect } \\
\text { on } \\
\text { choice }\end{array}$ \\
\hline $\begin{array}{l}\text { Study 2: } \\
\text { Race } \\
\text { experiment }\end{array}$ & $\begin{array}{l}\text { Purchase } \\
\text { intentions } \\
\text { following } \\
\text { exposure to } \\
\text { (fictional) } \\
\text { offensive ad } \\
\text { (treatment) } \\
\text { vs. non- } \\
\text { offensive ad } \\
\text { (control) over } \\
\text { short term } \\
\text { (immediately } \\
\text { following } \\
\text { exposure) vs. } \\
\text { long term (10 } \\
\text { days } \\
\text { following } \\
\text { exposure) } \\
\text { among } \\
\text { members of } \\
\text { high- power } \\
\text { group } \\
\text { (whites) and } \\
\text { low-power } \\
\text { group } \\
\text { (blacks) in a }\end{array}$ & $\begin{array}{l}347 \text { Prolific } \\
\text { respondents: } \\
201 \text { in the } \\
\text { treatment } \\
\text { group (103 } \\
\text { white; } 98 \\
\text { black), } \\
146 \text { in the } \\
\text { control } \\
\text { group ( } 80 \\
\text { white; } 66 \\
\text { black) }\end{array}$ & $\begin{array}{l}27.3 \% \text { and } \\
24.7 \% \\
\text { attritiona in } \\
\text { treatment and } \\
\text { control groups, } \\
\text { respectively; } \\
25.9 \% \text { and } \\
23.4 \% \text { attrition } \\
\text { among whites } \\
\text { and blacks, } \\
\text { respectively. }\end{array}$ & $\begin{array}{l}\mathrm{H} 1, \mathrm{H} 2 \\
\text { DV: } \\
\text { purchase } \\
\text { intentions }\end{array}$ & $\begin{array}{l}\text { Experiment } \\
\text { with } 2 \text { time } \\
\text { points, non- } \\
\text { randomized } \\
\text { samples. } \\
2 \text { (race) x } 2 \\
\text { (exposure: } \\
\text { short, long } \\
\text { term) } \times 2 \\
\text { (condition: } \\
\text { control, } \\
\text { treatment) }\end{array}$ & $\begin{array}{l}\text { TOP } \\
\text { effect } \\
\text { and } \\
\text { trigger } \\
\text { TOP } \\
\text { effect }\end{array}$ \\
\hline
\end{tabular}


US and UK

sample.

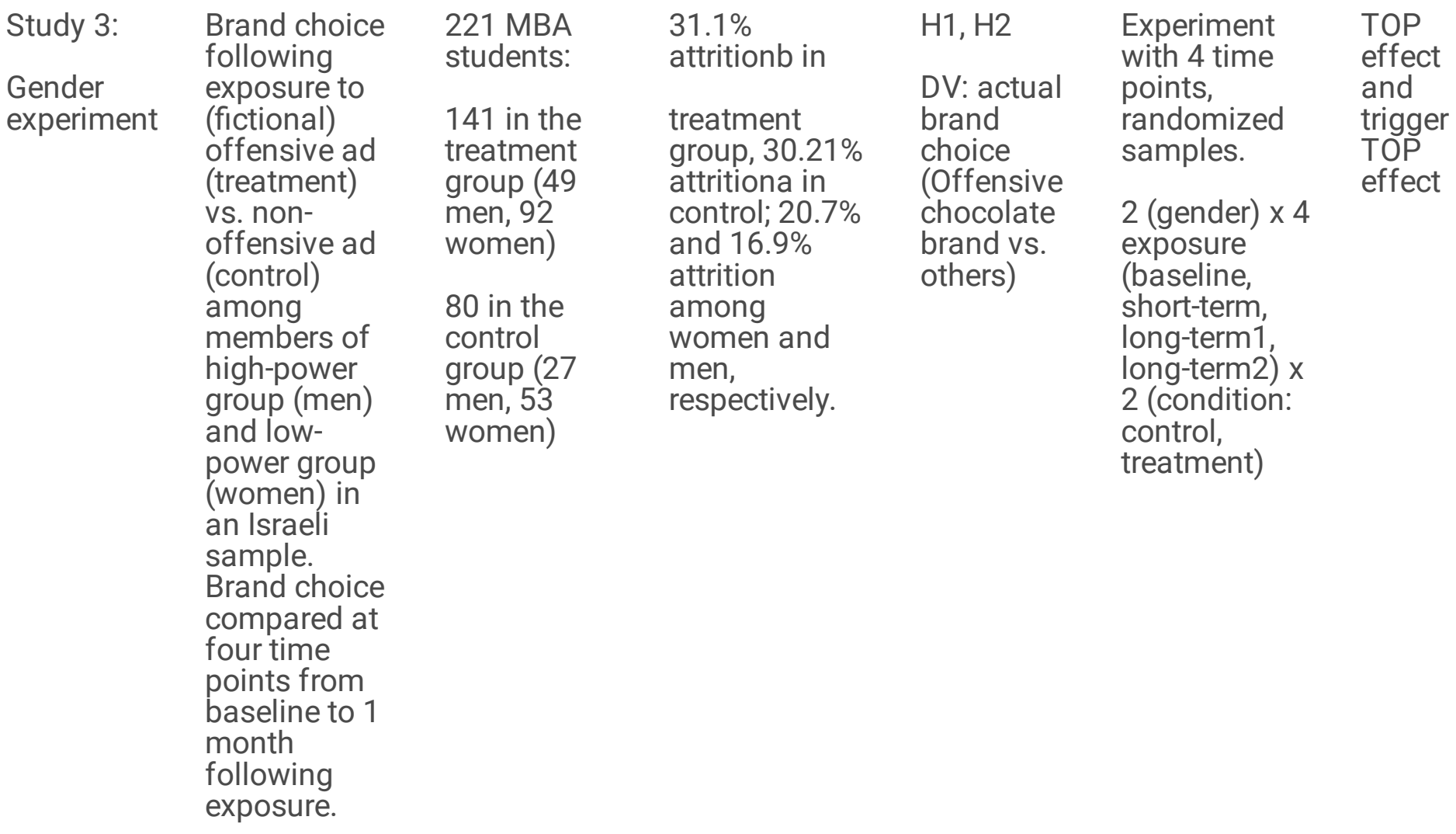

\begin{tabular}{|c|c|c|c|c|c|c|}
\hline $\begin{array}{l}\text { Study 4: } \\
\text { Mediation }\end{array}$ & $\begin{array}{l}\text { Simulated } \\
\text { brand choice } \\
\text { between a } \\
\text { beer brand } \\
\text { using } \\
\text { offensive ads } \\
\text { (treatment) } \\
\text { vs. a brand } \\
\text { using non- } \\
\text { offensive ads } \\
\text { (control) }\end{array}$ & $\begin{array}{l}105 \text { BA } \\
\text { students ( } 45 \\
\text { men, } \\
60 \text { women) }\end{array}$ & $\mathrm{N} / \mathrm{A}$ & $\begin{array}{l}\text { H3: Full } \\
\text { model } \\
\text { DV: } \\
\text { simulated } \\
\text { brand } \\
\text { choice }\end{array}$ & $\begin{array}{l}\text { Descriptive } \\
\text { survey of } \\
\text { responses } \\
\text { toward two } \\
\text { brands that } \\
\text { differ in } \\
\text { offensiveness } \\
\text { of their ads }\end{array}$ & $\begin{array}{l}\text { TOP } \\
\text { effect } \\
\text { and } \\
\text { trigger } \\
\text { TOP } \\
\text { effect }\end{array}$ \\
\hline
\end{tabular}

Notes: a No difference in level of perceived offensiveness between those who dropped out and those who completed the study $(\mathrm{t}(265)=-.36, p=.72)$; $\mathrm{b}$ Those who felt less offended were less likely to continue ( $\mathrm{M}$ Completed both parts $=5.50, \mathrm{SD}=1.70, \mathrm{M}$ Dropped out $=4.62, \mathrm{SD}=1.46, \mathrm{t}(173)=2.78, p<.01)$.

\section{Study 1a: Field Study (The Top Effect)}

Study $1 \mathrm{a}$ is a field study comparing sales of a major brand before and after the broadcast of potentially offensive ads. We selected a major local draft beer, but that has been on the market since 1950 in Europe and is currently marketed in the US as well. The brand targeted the male segment using ads with slogans such as "Say thank you, you're a man, with a man's drink". Recent ads of this brand have shown men drinking beer 
and laughing at women with exaggerated female behaviors (Haaretz 2015; Kyres 2016). Despite this seemingly chauvinist strategy, the brand seems to appeal equally to both men and women (London 2015).

\section{Method}

Twenty-four judges ( 12 women, 12 men, all academics who drink beer regularly) evaluated 11 ads that ran between 2014 and 2017, including eight commercials which aired on YouTube, and three public relations articles. They The judges rated the offensiveness of each ad from 1 (not offensive at all) to 10 (very offensive). The judges were recruited through social media, in a convenience sampling. The average age of the judges was $40.04, \mathrm{SD}=8.11($ Min age $=26$; Max age $=64)$.

The mean offensiveness rating was $3.15(\mathrm{SD}=1.56)$ for all judges, with mean ratings ranging from 1.08 to 4.58 for male judges and 1.25 to 8.25 for female judges (see table 2). Data on the brand's sales in thousands of liters was acquired from Storenext, a marketing and sales analytics company. ${ }^{1}$ Sales over the month preceding each ad's start date were compared with sales over the month following the ad's final appearance (e.g., for an ad aired in May 15, sales were calculated for the periods April 14-May 14 and May 15-June 15). We calculated daily sales by averaging sales over the relevant month.

${ }^{1}$ Monetary sales data was also provided, but this data was not used for direct analysis due to the possible confounding effects of price discounts and promotions.

\section{Table 2 Offensiveness ratings for ads of a well-known beer brand ( 24 judges; 1 = not offensive at all; 10 = very offensive)}




\begin{tabular}{|c|c|c|c|c|c|c|c|c|}
\hline & $\begin{array}{l}\text { Date aired } \\
\text { on Youtube }\end{array}$ & $M$ & SD & Mmen & SDmen & Mwomen & SDwomen & $\mathrm{t}$ \\
\hline Ad 1 & $27 / 02 / 2014$ & 3.50 & 2.99 & 3.33 & $(2.77)$ & 8.25 & $(1.89)$ & $-5.095^{\star \star \star}$ \\
\hline Ad 2 & 03/03/2014 & 2.13 & 2.58 & 2.25 & $(1.66)$ & 4.33 & $(2.50)$ & $-2.407 \star \star$ \\
\hline Ad 3 & $15 / 05 / 2014$ & 5.67 & 3.42 & 2.08 & $(1.17)$ & 6.33 & $(2.67)$ & $-5.048 * \star \star$ \\
\hline Ad 4 & $29 / 07 / 2014$ & 1.38 & .71 & 1.08 & $(2.89)$ & 1.25 & $(.45)$ & -1.076 \\
\hline Ad 5 & $08 / 04 / 2015$ & 4.21 & 2.89 & 3.08 & $(2.64)$ & 7.17 & $(2.69)$ & $-3.749 \star \star$ \\
\hline Ad 6 & $21 / 05 / 2015$ & 1.17 & .38 & 2.50 & $(7.83)$ & 2.84 & $(2.48)$ & -.178 \\
\hline $\operatorname{Ad} 7$ & 07/06/015 & 4.79 & 3.12 & 2.83 & $(3.46)$ & 1.42 & $(.90)$ & 1.373 \\
\hline Ad 8 & $11 / 07 / 2015$ & 5.13 & 3.34 & 1.17 & $(.390)$ & 1.58 & $(.90)$ & 14.973 \\
\hline Ad 9 & $07 / 12 / 2015$ & 3.88 & 2.59 & 2.67 & $(2.06)$ & 5.08 & $(2.57)$ & $-2.539 *$ \\
\hline Ad 10 & $04 / 06 / 2017$ & 1.38 & .71 & 4.58 & (3.18) & 5.00 & (3.19) & -.321 \\
\hline Ad 11 & $16 / 07 / 2017$ & 3.29 & 2.33 & 2.75 & $(2.261)$ & 5.57 & $(2.774)$ & $-2.823^{\star \star}$ \\
\hline
\end{tabular}

${ }^{\star} p<.05 ;{ }^{*} p<.01 ; * \star \star x p<.001$

\section{Results and Discussion}

We tested our hypotheses using hierarchical regression to predict the difference in daily sales in liters over the month preceding versus the month following a given ad. We first entered, as a control variable, the cumulative offensiveness of the ads that ran before a new ad's introduction (to capture potential habituation). We then entered a "season" variable into the equation to account for seasonal effects on sales (e.g., sales promotions in the winter or sports events in the summer). In the third step, we entered the judges' ratings of the ad's offensiveness as a predictor. The results are summarized in table 3.

In the next stage of analysis, we compared data for the three ads that were perceived as least offensive (Ads 4,6 , and 10, with total mean offensiveness ratings of 1.17-1.38; see table 3 ) and the three perceived as most offensive (Ads 3, 7, and 8, with total mean ratings of 4.79-5.67). The results show an increase in sales in the month following the appearance of the most offensive ads relative to the month before the ads appeared, compared with a decline in sales in the month following the non-offensive ads compared to the preceding month (M Offensive ads delta sales $=73.33, \mathrm{SD}=69.89, \mathrm{M}$ Non-offensive ads delta sales $=-32.96, \mathrm{SD}=$ $31.34, t(4)=3.25, p<.05)$. As can be seen from table 3 , the ad's offensiveness is the only significant predictor of the change in sales. When the ad was rated as more offensive, sales increased. These results confirm $\mathrm{H} 1$ : 
Exposure to offensive ads will lead to a more positive consumer response to the brand over time, compared to a less-offensive ad (the TOP effect).

\section{Table 3 Predicting a Change in Sales Following Exposure to Offensive Ads}

\begin{tabular}{|c|c|c|c|}
\hline Model & Variables & Estimate & SE \\
\hline & Constant & 9.35 & 22.98 \\
\hline \multirow[t]{4}{*}{1} & Cumulative offensiveness of preceding ads & 7.41 & 7.99 \\
\hline & $\mathrm{R} 2=.087$ & & \\
\hline & Constant & -11.31 & 39.14 \\
\hline & Cumulative offensiveness of preceding ads & 8.071 & 8.31 \\
\hline & Season (dummy: summer/winter) & 26.65 & 40.16 \\
\hline & $\mathrm{R} 2=.135$ & & \\
\hline & Constant & -92.79 & 27.42 \\
\hline & Cumulative offensiveness & -13.58 & 6.48 \\
\hline & Season (dummy: summer/winter) & 5.38 & 21.94 \\
\hline & Ad's offensiveness & $41.64^{*}$ & 9.07 \\
\hline & $\mathrm{R} 2=.784^{\star}$ & & \\
\hline${ }^{\star} p<.01$ & & & \\
\hline
\end{tabular}

In study $1 \mathrm{a}$, we were unable to derive sales for each gender segment. Therefore, in Study $1 \mathrm{~b}$ we tested brand choice among men and women.

\section{Study 1b: Short Survey (Trigger Top Effect)}


The goal of Study $1 \mathrm{~b}$ is to explore the Trigger TOP effect in the field. To do so we ran a pre-test examining the perceived offensiveness of six beers, and a survey examining the beer brand choice of men and women. The pre-test was run among a different sample from Study $1 \mathrm{~b}$, since the question assessing the level of offense could prime a feeling of offense in the short term, and thus influence the respondents' beer brand choice. During the month previous to data collection of both the pre-test and Study $1 \mathrm{~b}$, the advertisements of the beer brands used in the surveys did not appear in media, thus the surveys examine long-term effects.

\section{Pre-test}

A short survey was distributed among 287 respondents using social media (66.6\% women). This survey included one question assessing the level of offensiveness of six well-known beers, including the beer analyzed in Study 1a. Question was "How offensive are the following beer brands?" (1-not offensive at all to 7-very offensive). In addition, we asked to report demographics.

Results indicated that the beer used in Study 1 a was indeed perceived as more offensive (Moffense $=3.34$, $\mathrm{SD}=.13$ ) compared to the rest of the beers (Moffense ranged between 1.92-2.30, SD ranged between .08-.10, $F(5,282)=29.91, p<.001)$. Pairwise comparisons showed significant difference between the level of offense of this beer and each of the other beers ( $M$ difference in pairwise comparisons ranged from 1.04-1.42, all differences were significant at $p<.001$ ). This confirmed that the beer used in Study $1 \mathrm{a}$ is indeed perceived as the most offensive beer. When examining the difference in perceived offensiveness of this beer between men and women, results indicate that women perceive it as more offensive than men $\left(M_{\text {men }}=2.88, S D=2.07 ; M\right.$ women $=3.58, \mathrm{SD}=2.25, \mathrm{t}(204.98)=-2.63, p<.01)$.

\section{Sample and procedure}

Two-hundred-and-sixty-one MBA students (72.7\% women) who indicated that they drink beer regularly were asked to answer a one-minute survey during class. Participants were asked two questions: (1) their gender, and (2) which beer they will choose if we would distribute free beers out of six brands commonly sold locally.

\section{Results and Discussion}

Based on the data obtained from the short survey, we calculated the proportion of men and women choosing the brand of beer under study. Among the women, the highest percentage (30.9\%) chose the brand of beer that was analyzed in study $1 \mathrm{a}$. Among the men, this brand was the second-favorite, chosen by $21.3 \%$ of the male participants (after Tuborg, at 40.5\%). Considering the two leading brands, choice and gender were related: $\chi^{2}(1)=3.45, p<.05$. These results point to a potential trigger TOP effect. 
Studies $1 \mathrm{a}$ and $1 \mathrm{~b}$ are field studies that suggest a positive consumer response over time to offensive ads. Studies 2 and 3 will examine these effects using an experimental design.

\section{Experimental Studies}

"Buzz," or familiarity effects, might help explain a positive consumer response to offensive ads, on the grounds that "all publicity is good publicity." Chen and Berger (2013) demonstrated such an effect with respect to book sales following negative book reviews. Our next three studies were designed to rule out this alternative explanation. Studies 2 and 3 were lab experiments aimed at testing hypotheses 1 and 2 . Study 4 was a survey designed to clarify the mechanism at play (hypothesis 3 ).

In study 2 we turned from gender to race, examining ads deemed to be offensive to members of the minority black communities in the United States and United Kingdom. We returned to gender in study 3.

\section{Pretest}

Before embarking on the experimental studies, we conducted a pretest aimed at confirming the validity of our intended manipulation, and the power difference between two groups in each experiment (blacks vs. whites, and women vs. men). Pretest participants comprised 102 Business students ( 66 women, 36 men). The students were randomly presented with one of four ads (a race- or gender-offensive ad or a comparable neutral ad) and assessed on various questions regarding the offensiveness of the ad and social power of the relevant group (see table 4 for the pretest results). The pre-test results confirmed that the race- offensive and non-offensive-neutral ads indeed differed in their perceived offensiveness ( $M$ race-control ad $=1.27, S D=.83$; $M$ race-treatment ad $=5.55, S D=2.14, t(98)=-16.62, p<.001$ ), and that blacks were perceived as having low social power compared to whites $(\mathrm{M}$ white $=5.85, \mathrm{SD}=1.03$; $\mathrm{M}$ black $=3.28, \mathrm{SD}=1.39, \mathrm{t}(99)=$

$-14.02, p<.001)$. Likewise, the pre-test showed that the gender-offensive and non-offensive ads differed in their perceived offensiveness $(\mathrm{M}$ gender-control $=1.40, \mathrm{SD}=.97 ; \mathrm{M}$ gender-treatment $=5.76, \mathrm{SD}=1.77, \mathrm{t}(99)$ $=-21.92, p<.001)$, and that women were perceived as having low social power compared to men ( $\mathrm{M}$ men $=$ $6.16, \mathrm{SD}=.90 ; \mathrm{M}$ women $=4.64, \mathrm{SD}=1.21, \mathrm{t}(99)=-10.67, p<.001)$.

\section{Table 4 Pretest results (1 = strongly disagree, 7 = strongly agree)}




\begin{tabular}{|c|c|c|c|c|c|c|}
\hline \multirow[t]{2}{*}{ Item } & \multicolumn{2}{|c|}{$\begin{array}{l}\text { Racially offensive } \\
\text { ad }\end{array}$} & \multicolumn{4}{|c|}{ Gender-offensive ad } \\
\hline & Control & Treatment & $\mathrm{t}$ & Control & Treatment & $t$ \\
\hline The ad is offensive & $\begin{array}{l}1.27 \\
(.83)\end{array}$ & $\begin{array}{l}5.55 \\
(2.14)\end{array}$ & $\begin{array}{l}-16.62 \\
\star \star\end{array}$ & $\begin{array}{l}1.40 \\
(.97)\end{array}$ & $\begin{array}{l}5.76 \\
(1.77)\end{array}$ & -21.92 \\
\hline I was personally hurt by the ad & $\begin{array}{l}1.21 \\
(.56)\end{array}$ & $\begin{array}{l}3.43 \\
(2.15)\end{array}$ & -9.74 ** & $\begin{array}{l}1.28 \\
(.67)\end{array}$ & $\begin{array}{l}4.30 \\
(2.24)\end{array}$ & $\begin{array}{l}-13.09 \\
* \star\end{array}$ \\
\hline The ad reinforces stereotypes & $\begin{array}{l}1.53 \\
(1.29)\end{array}$ & $\begin{array}{l}5.53 \\
(2.02)\end{array}$ & $\begin{array}{l}-14.39 \\
\star \star\end{array}$ & $\begin{array}{l}1.67 \\
(1.38)\end{array}$ & $\begin{array}{l}5.94 \\
(1.59)\end{array}$ & -20.35 \\
\hline $\begin{array}{l}\text { The ad creates social harm to some } \\
\text { groups in society }\end{array}$ & $\begin{array}{l}1.38 \\
(1.05)\end{array}$ & $\begin{array}{l}5.58 \\
(1.97)\end{array}$ & $\begin{array}{l}-16.89 \\
\star \star\end{array}$ & $\begin{array}{l}1.48 \\
(1.05)\end{array}$ & $\begin{array}{l}5.79 \\
(1.71)\end{array}$ & -22.95 \\
\hline $\begin{array}{l}\text { The brand in the ad is affiliated } \\
\text { with men/white people }\end{array}$ & $\begin{array}{l}1.65 \\
(1.44)\end{array}$ & $\begin{array}{l}5.18 \\
(2.20)\end{array}$ & $\begin{array}{l}-12.54 \\
\star \star\end{array}$ & $\begin{array}{l}1.55 \\
(1.19)\end{array}$ & $\begin{array}{l}5.78 \\
(1.69)\end{array}$ & -20.52 \\
\hline $\begin{array}{l}\text { Men/white people tend to purchase } \\
\text { the brand shown in the ad }\end{array}$ & $\begin{array}{l}2.01 \\
(1.50)\end{array}$ & $\begin{array}{l}3.31 \\
(1.93)\end{array}$ & $-5.19 * *$ & $\begin{array}{l}1.84 \\
(1.51)\end{array}$ & $\begin{array}{l}4.19 \\
(1.94)\end{array}$ & $\begin{array}{l}-10.15 \\
\star \star\end{array}$ \\
\hline $\begin{array}{l}\text { From the ad, men/white people } \\
\text { appear to have higher social power } \\
\text { than women/black people }\end{array}$ & $\begin{array}{l}1.45 \\
(1.22)\end{array}$ & $\begin{array}{l}5.06 \\
(2.29)\end{array}$ & $\begin{array}{l}-12.32 \\
* \star\end{array}$ & $\begin{array}{l}1.36 \\
(.96)\end{array}$ & $\begin{array}{l}5.17 \\
(2.13)\end{array}$ & -15.91 \\
\hline $\begin{array}{l}\text { The ad shows that women/black } \\
\text { people are inferior to men/white } \\
\text { people }\end{array}$ & $\begin{array}{l}1.57 \\
(1.43)\end{array}$ & $\begin{array}{l}5.43 \\
(2.01)\end{array}$ & $-14.80 \star \star$ & $\begin{array}{l}1.46 \\
(1.17)\end{array}$ & $\begin{array}{l}5.45 \\
(1.98)\end{array}$ & -17.35 \\
\hline The brand in the ad is powerful & $\begin{array}{l}1.40 \\
(1.06)\end{array}$ & $\begin{array}{l}4.59 \\
(2.17)\end{array}$ & $\begin{array}{l}-12.82 \\
\star *\end{array}$ & $\begin{array}{l}1.78 \\
(1.52)\end{array}$ & $\begin{array}{l}5.84 \\
(1.88)\end{array}$ & $\begin{array}{l}-17.07 \\
* \star\end{array}$ \\
\hline \multirow{2}{*}{$\begin{array}{l}\text { The perceived level of social power } \\
\text { (opportunities, resources, status) }\end{array}$} & \multicolumn{2}{|c|}{ Whites = 5.85 (1.03) } & \multirow[t]{2}{*}{$\begin{array}{l}-10.67 \\
\star \star\end{array}$} & \multicolumn{2}{|c|}{ Men = $6.16(.90)$} & -14.02 \\
\hline & \multicolumn{2}{|c|}{ Blacks = 3.28 (1.39) } & & \multicolumn{2}{|c|}{$\begin{array}{l}\text { Women = } 4.64 \\
(1.21)\end{array}$} & \\
\hline
\end{tabular}

** $p<.001$

\section{Power Analysis}

The required sample size for studies 2, 3, and 4 was determined using OpenEpi (version 3) for an unmatched case-control study (with 1-alpha $=95 \%$, beta $=80 \%$ ). We purposely assigned more participants to the offensive ad conditions than to the control conditions to protect against potential attrition in the offensive condition. Thus, the ratio of controls to cases was .60. The ratio of unexposed/exposed was set with an estimated $30 \%$ outcome in the unexposed (control) group, compared to a $70 \%$ outcome in the exposed treatment group (odds ratio $=5.44$ ). The recommended sample size in the control condition is 23 participants, and in the treatment group, 38 participants (Fleiss 2011). All studies satisfy these requirements. 


\section{Study 2: Top And Trigger Top With A Racist Ad \\ Method}

\section{Participants and Procedure.}

The ads used in the manipulation were based on real ads that had been criticized as being offensive. In this study, we tested the short- and long-term effects of exposure to racially offensive vs. non-offensive-neutral ads on purchase intentions for "Bubbles" soap. In the offensive version a dark skinned family was in the before picture and light skinned family was in the after picture, with the soap in the center of the ad. The control had only the product in the center. High and low-power groups (white and black participants, respectively) answered two questionnaires: the first immediately after exposure to an ad (short-term), and the second 10 days later (long-term). The ad was only presented once, during the first phase of the study.

Participants were recruited from the US and UK through the Prolific online survey platform, with participants screened based on race (white/black). Participants were paid for their participation only after they completed both parts of the study. About a quarter of the participants dropped out between the first and second parts of the study (see table 1).

In the first questionnaire, we asked respondents to indicate their skin color as a dichotomous variable (tending to be light or tending to be dark). Four participants were excluded from the treatment condition and 14 from the control condition due to a mismatch between their reported skin color and their race categorization. Overall, 347 respondents participated in both stages of the study (Mean age $=34.64 ; \mathrm{SD}=9.96$; $58.8 \%$ women). In the treatment (offensive ad) group, 201 participants (103 white and 98 black) completed both questionnaires, while in the control non-offensive-neutral ad condition, 146 participants (80 white and 66 black) completed both questionnaires.

At the first time point, participants were shown the appropriate ad for their experimental condition. They were then asked a series of questions about the ad and themselves. At the second time point participants only responded to the questionnaire, without viewing the ad again.

\section{Measures.}

The following measures were used in the first questionnaire: offensiveness of the ad, purchase intentions, feelings of race group discrimination, and demographic controls (age, gender, income, and family status). The second questionnaire repeated the offensiveness, purchase intentions, and race group discrimination measures, while also testing participants' memory of the ad (the brand name and the ad's content).

First, offensiveness of the ad was measured via one-item ( $1=$ not offensive at all to 7 = very offensive, based on Alwitt and Prabhaker, 1994.To divert attention from the goal of the study, we also asked a series of questions about other attitude constructs (pleasant or unpleasant; positive or negative; favorable or unfavorable). These were not analyzed for the current study. 
Purchase intentions were measured with the one-item: "If I will want to buy this product, I'll probably buy this brand" on a 7-point scale (1 = I don't agree at all, 7 = I totally agree) similar to MacKenzie et al., 1986.

Feelings of race group discrimination were measured with one item based on Szymanski and Balsam (2011). Respondents were asked: "How often have you felt that people of your race group are discriminated against in our society?" on a 7-point scale ( $1=$ very rarely, $7=$ very frequently.

Memory of the brand name (second questionnaire only) was measured through the question, "What is the brand that appeared in the ad from 10 days ago?" This was recorded as a dichotomous variable $(0=$ did not correctly remember the brand's name, $1=$ correctly remembered the name). Memory of the ad's content was measured by asking respondents to describe the content of the ad they had seen. This again was measured as a dichotomous response ( $0=$ did not correctly recall the content, $1=$ correctly recalled the content).

\section{Results and Discussion}

The ad shown to the treatment group was indeed perceived as more offensive than the non-offensive- neutral control group ( $M$ race-control $\mathrm{ad}=1.29, \mathrm{SD}=.95 ; \mathrm{M}$ race-treatment $\mathrm{ad}=5.64, \mathrm{SD}=2.18$ ). The descriptive results for the two groups (white and black respondents) are summarized in table 5.

\section{Table 5 Descriptive Results for Study 2}




\begin{tabular}{|llllll|}
\hline Study 2 & Race: Control & & \\
& White $(\mathrm{n}=80)$ & & & \\
\hline Variables & Short-term & Long-term & t & $\mathrm{p}$ \\
\hline Feelings of discrimination & $2.16(1.54)$ & $2.05(1.42)$ & .89 & .374 \\
\hline Ad's offensiveness & $1.27(.95)$ & $1.45(.86)$ & -1.72 & .090 \\
\hline Memory of ad's name & - & $21.3 \%$ & - & - \\
\hline Memory of ad's content & - & $58.8 \%$ & - & - \\
\hline Purchase intentions & $2.84(1.49)$ & $2.74(1.35)$ & .71 & .479 \\
\hline & Black (n=66) & & & \\
\hline Variables & Short-term & Long-term & t & p \\
\hline Feelings of discrimination & $5.64(1.66)$ & $5.70(1.71)$ & -.49 & .626 \\
\hline Ad's offensiveness & $1.30(.944)$ & $1.45(.88)$ & -1.07 & .290 \\
\hline Memory of ad's name & - & $24.3 \%$ & - & - \\
\hline Memory of ad's content & - & $50.0 \%$ & - & - \\
\hline Purchase intentions & $2.35(1.54)$ & $2.48(1.53)$ & -1.00 & .321 \\
\hline & & & & \\
\hline
\end{tabular}




\begin{tabular}{|c|c|c|c|c|}
\hline \multicolumn{5}{|c|}{ Race: Treatment } \\
\hline \multicolumn{5}{|c|}{ White $(n=103)$} \\
\hline Variables & Short-term & Long-term & $\mathrm{t}$ & $\mathrm{p}$ \\
\hline Feelings of discrimination & $2.82(1.85)$ & $2.19(.79)$ & 3.46 & .001 \\
\hline Ad's offensiveness & $5.50(2.18)$ & $4.10(2.32)$ & 5.77 & .000 \\
\hline Memory of ad's name & - & $24.3 \%$ & - & - \\
\hline Memory of ad's content & - & $58.8 \%$ & - & - \\
\hline Purchase intentions & $1.97(1.72)$ & $2.49(1.70)$ & -2.29 & .024 \\
\hline \multicolumn{5}{|c|}{ Black (n=98) } \\
\hline Variables & Short-term & Long-term & $\mathrm{t}$ & $\mathrm{p}$ \\
\hline Feelings of discrimination & $5.92(1.52)$ & $6.04(.91)$ & -.88 & .379 \\
\hline Ad's offensiveness & $5.84(2.13)$ & $5.55(2.06)$ & 1.16 & .248 \\
\hline Memory of ad's name & - & $13.0 \%$ & - & - \\
\hline Memory of ad's content & - & $70.7 \%$ & - & - \\
\hline Purchase intentions & $1.64(1.39)$ & $2.75(1.85)$ & -5.70 & .000 \\
\hline
\end{tabular}

Hypothesis 1 predicted that exposure to an offensive ad would lead to more positive consumer response to the brand over time compared to a control ad. To examine $\mathrm{H} 1$, we ran a repeated-measures ANOVA with ad condition as the between-subjects factor and purchase intentions over time as the within- subjects factor. A main effect of time since exposure was evident $(F(1,344)=17.23, p<.001)$, and the interaction between time since exposure and ad condition was significant $(F(1,344)=16.65, p<.001)$. The results showed a positive and significant effect on purchase intentions 10 days after exposure to the ad in the treatment condition $(F(1,204)=30.72, p<.001)$, but not in the control condition $(F(1,145)=.005, p=.95)$. Thus, $\mathrm{H} 1$ is confirmed.

The two "Bubble soap" ads differ in ways other than offensiveness. Most obviously, the treatment ad features smiling, happy, healthy-looking people, while the control ad shows no people at all. It might be that our initial results simply reflect the presence versus absence of people in the image. Our next analysis, to test $\mathrm{H} 2$, addresses this point.

$\mathrm{H} 2$ posited that group membership would moderate the relationship between exposure to offensive ads and consumer response, with a stronger effect in the low-power group (in this case, black consumers). To examine this hypothesis, we ran separate repeated-measures ANOVAs for the treatment and control conditions, entering race as a between-subjects factor and purchase intentions at both time points as the within-subject factor. The interaction term of race by time since exposure was significant only in the 
treatment (offensive ad) condition $(F(1,198)=4.01, p<.05)$, and not in the control condition $(F(1,112)=$ $1.73, p=.19)$. The results are displayed in figure 1 . As can be seen, these results reveal a steeper increase in purchase intentions over time following exposure to an offensive ad in the low-power group compared with the high-power group. Thus, $\mathrm{H} 2$ is confirmed.

Probing the findings further, in the short term (immediately after exposure to the ad), the difference in purchase intentions between the control and treatment conditions was significant among both the white (M Difference $=.87, \mathrm{SE}=.23, p<.001$ ) and black participants ( $\mathrm{M}$ Difference $=.71, \mathrm{SE}=.25, p<.01$ ). That is, in the short term both blacks and whites had higher purchase intentions after viewing the control ad compared with the offensive ad. However, in the long term (10 days after viewing the ad), purchase intentions in the treatment condition rose to match those of the control condition among both groups of respondents, white (M Difference $=.25, \mathrm{SE}=.24, p=.30$ ) and black (M Difference $=-26, \mathrm{SE}=.24, p=.31$ ). Thus, it appears that participants in the treatment group initially showed lower purchase intentions, presumably as a response to the offensive nature of the ad. However, over time, their purchase intentions recovered to the levels of the control.

Could mere familiarity-operationalized by whether participants remembered the name of the (fictional) brand over time-help explain this phenomenon? To examine the role of participants' memory of the brand, we used t-tests to compare purchase intentions among those who remembered the name of the brand at the time of the second questionnaire versus those who did not. Separate analyses were conducted for each group (blacks and whites) within the treatment condition. It is important to note that fewer blacks than whites recalled the name of the brand $(13.0 \%$ compared to $24.3 \%, z(199)=2.05, p<.05$, in a proportion test for independent samples). However, among blacks who did remember the brand's name, fewer wanted to purchase the brand ( $\mathrm{M}$ brand-aware $=1.64, \mathrm{SD}=1.03, \mathrm{M}$ not brand-aware $=2.68, \mathrm{SD}=1.76, \mathrm{t}(20.6)=2.78$, $p<.05)$. In contrast, among whites, purchase intentions did not differ between those who did and did not recall the brand's name ( $\mathrm{M}$ brand-aware $=2.20, \mathrm{SD}=1.63, \mathrm{M}$ not brand-aware $=2.58, \mathrm{SD}=.17, \mathrm{t}(101)=.96, p$ $=.34$ ). Thus, the familiarity explanation for the observed consumer response is not valid.

Moreover, in the treatment group, the positive interaction was evident even though blacks remembered the content of the ad more than whites (70.7\% among blacks compared to $58.8 \%$ among whites, $z(199)=-1.76$, $p<.05$, in a proportion test for independent samples). This means that a decayed memory of the ad's offensiveness did not trigger the observed effect. Furthermore, in the treatment group, memory of the brand's name was not related to memory of the content of the $\operatorname{ad}\left(\chi^{2}(1)=1.27, p=.33\right)$. Thus, our findings suggest that different unconscious processes drive consumer response in the two groups.

While Study 2 yielded a positive recovery trend (though with no significant difference from the long- term response in the control group), our data in this study were still limited to a fairly short time lag (10 days). Study 3 was designed to explore this effect over a longer time period to see if the trend persists. In this study, we examined the effect of exposure to an offensive ad on actual brand choice at four time points: at baseline (before exposure to the ad), immediately following exposure, 10 days after exposure, and a month after exposure.

\section{Study 3: Top And Trigger Top With A Sexist Ad}

Page 19/38 


\section{Method}

\section{Participants and Procedure.}

Study 3 was an actual brand choice experiment involving three branded chocolate bars (the offensive chocolate brand, vs. two other brands). In this study, high and low-power groups (men and women, respectively) were randomly exposed to either an offensive ad or a neutral ad for a chocolate brand. In the offensive version a man was facing a woman saying: "woman, I'm sick of you, I get tired of all of you so quickly", with the statement "you are not you when you are hungry", the chocolate brand was in the center of the ad. The control had only the product in the center with a man and a woman but without any statements. Participants were asked to answer three questionnaires. The first questionnaire contained the baseline and short-term questions, with the latter presented immediately after participants were exposed to the ad. The second was collected after 10 days (long-term1), and the third was collected after a month (long-term2). As in study 2 , the ads were shown to participants only once, at the time of the initial questionnaire.

Participants were drawn from MBA students. Three hundred and eighteen students took part in the initial stage of the study, of whom 221 completed all three stages (Mean age $=28.17 ; \mathrm{SD}=5.8 ; 65.6 \%$ women). The final sample comprised 141 students (65.2\% women) in the treatment group and 80 (66.2\% women) in the control group (for details on attrition at each stage see table 1). Respondents who completed all three questionnaires received course credit, along with bars of their preferred chocolate at each measurement point.

\section{Measures.}

As noted above, data were collected at four time points: at baseline, immediately after exposure to the ad (short-term), 10 days after exposure (long-term1) and one month after exposure (long-term2). At baseline, we measured feelings of group discrimination, brand choice, and controls (age, income, family status, and whether the respondent likes chocolate). The short-term questions assessed offensiveness of the ad and then repeated the previous (non-control) measures. As in study 2, the two long-term questionnaires repeated the earlier measures while also assessing memory of the brand shown in the ad, and memory of the ad's content.

The brand choice item asked participants which of three knowns chocolate brands they would choose to receive after completion. These responses were later recoded as the offensive chocolate brand versus the competition ( 0 others, $1=$ the offensive chocolate brand). The remaining variables were measured as in study 2. Again, the offensiveness scale also measured other attitude constructs (not analyzed) as a way to deflect attention from the goal of the study.

\section{Results and Discussion}


Study 3 was designed to re-examine hypotheses 1 and 2 with a different sample and different set of offensive and non-offensive ads. In addition, it aimed to test whether the effect observed in study 2 ten days after exposure to an offensive ad would persist over a longer time period, or whether it would disappear over time (regression to the mean).

First, we used t-tests to confirm that the treatment and control groups indeed differed in perceived offensiveness $(\mathrm{M}$ gender-control ad $=2.72, \mathrm{SD}=1.60 ; \mathrm{M}$ gender-treatment $\mathrm{ad}=5.50, \mathrm{SD}=1.70, \mathrm{t}(218)=$ $-11.87, p<.001$ ). Second, we used the McNemar test (a repeated-measures version of the chi-squared test) to check for differences between the proportions of respondents choosing the offensive chocolate brand at the four time points among women versus men, and within the control group versus the treatment group. We found no significant differences over the four time points for either men or women in the control group. However, significant differences were found among both men and women in the treatment group. These findings were particularly notable for women. For this group we found a significant decrease between baseline and short- term brand choice $(p<.05)$. However, we then found a significant increase between the short term and long- term1 $(p<.01)$, the short term and long-term $2(p<.01)$, and between the baseline and long-term2 $(p<.05)$. See table 6 .

\section{Table 6 Descriptive Results for Study 3}

\begin{tabular}{|llllllll|}
\hline Study 3 & & \multicolumn{5}{c|}{ Gender: Control } \\
& & \multicolumn{5}{c|}{ Men (n=27) } \\
\hline Variables & Baseline & Short-term & Long-term1 & Long-term2 & t/F & p \\
\hline Feelings of discrimination & $2.70(1.44)$ & $2.78(1.01)$ & $2.81(1.11)$ & $3.04(.94)$ & .49 & .691 \\
\hline Ad's offensiveness & - & $2.22(1.22)$ & $2.96(1.09)$ & $2.74(1.13)$ & 2.95 & .071 \\
\hline Memory of ad's name & - & - & $65.4 \%$ & $63.0 \%$ & - & - \\
\hline Memory of ad's content & - & - & $42.3 \%$ & $51.9 \%$ & - & - \\
\hline Offensive brand choice & $44.4 \%$ & $40.7 \%$ & $48.1 \%$ & $37 \%$ & & \\
\hline Women (n=53) & & & & & & \\
\hline Variables & Baseline & Short-term & Long-term1 & Long-term2 & t/F & p \\
\hline Feelings of discrimination & $4.92(1.04)$ & $4.81(1.14)$ & $5.02(1.08)$ & $5.00(1.19)$ & .67 & .573 \\
\hline Ad's offensiveness & - & $2.98(1.72)$ & $3.31(1.34)$ & $3.54(1.34)$ & 2.06 & .138 \\
\hline Memory of ad's name & - & - & $69.2 \%$ & $60.4 \%$ & - & - \\
\hline Memory of ad's content & - & - & $32.1 \%$ & $54.7 \%$ & - & - \\
\hline Offensive brand choice & $39.6 \%$ & $41.5 \%$ & $35.8 \%$ & $32.1 \%$ & & \\
\hline
\end{tabular}




\title{
Gender: Treatment
}

\author{
Men $(n=49)$
}

\begin{tabular}{|c|c|c|c|c|c|c|c|}
\hline Variables & Baseline & $\begin{array}{l}\text { Short- } \\
\text { term }\end{array}$ & $\begin{array}{l}\text { Long- } \\
\text { term1 }\end{array}$ & $\begin{array}{l}\text { Long- } \\
\text { term2 }\end{array}$ & $t / F$ & $\mathrm{p}$ & Post-hoc \\
\hline $\begin{array}{l}\text { Feelings of } \\
\text { discrimination }\end{array}$ & $\begin{array}{l}2.67 \\
(1.68)\end{array}$ & $\begin{array}{l}2.98 \\
(1.66)\end{array}$ & $\begin{array}{l}2.86 \\
(1.62)\end{array}$ & $\begin{array}{l}3.18 \\
(1.73)\end{array}$ & 3.10 & .036 & Baseline $\neq$ Long-term2 \\
\hline $\begin{array}{l}\text { Ad's } \\
\text { offensiveness }\end{array}$ & - & $\begin{array}{l}5.04 \\
(1.72)\end{array}$ & $\begin{array}{l}4.16 \\
(1.72)\end{array}$ & $\begin{array}{l}4.49 \\
(1.52)\end{array}$ & 4.42 & .017 & $\begin{array}{l}\text { Short-term } \neq \text { = Long-term } 1 \\
\text { Short-term } \neq \text { Long-term } 2\end{array}$ \\
\hline $\begin{array}{l}\text { Memory of } \\
\text { ad's name }\end{array}$ & & & $77.6 \%$ & $71.4 \%$ & & & \\
\hline $\begin{array}{l}\text { Memory of } \\
\text { ad's content }\end{array}$ & - & - & $40.0 \%$ & $37.5 \%$ & - & - & \\
\hline $\begin{array}{l}\text { Offensive } \\
\text { brand choice }\end{array}$ & $38.8 \%$ & $30.6 \%$ & $40.8 \%$ & $36.7 \%$ & & & \\
\hline \multicolumn{8}{|c|}{ Women $(n=92)$} \\
\hline Variables & Baseline & $\begin{array}{l}\text { Short- } \\
\text { term }\end{array}$ & $\begin{array}{l}\text { Long- } \\
\text { term1 }\end{array}$ & $\begin{array}{l}\text { Long- } \\
\text { term2 }\end{array}$ & $\mathrm{t} / \mathrm{F}$ & $\mathrm{p}$ & Post-hoc \\
\hline $\begin{array}{l}\text { Feelings of } \\
\text { discrimination }\end{array}$ & $\begin{array}{l}4.86 \\
(1.26)\end{array}$ & $\begin{array}{l}5.00 \\
(1.16)\end{array}$ & $\begin{array}{l}5.10 \\
(1.28)\end{array}$ & $\begin{array}{l}5.13 \\
(1.38)\end{array}$ & 2.89 & .138 & \\
\hline $\begin{array}{l}\text { Ad's } \\
\text { offensiveness }\end{array}$ & - & $\begin{array}{l}5.74 \\
(1.64)\end{array}$ & $\begin{array}{l}5.04 \\
(1.53)\end{array}$ & $\begin{array}{l}5.39 \\
(1.37)\end{array}$ & 8.50 & .000 & $\begin{array}{l}\text { Short-term } \neq \text { Long-term1; } \\
\text { Short-term } \neq \text { \&ong-term2; Long- } \\
\text { term1 } \neq \text { Long-term2 }\end{array}$ \\
\hline $\begin{array}{l}\text { Memory of } \\
\text { ad's name }\end{array}$ & - & - & $62.2 \%$ & $69.2 \%$ & - & - & \\
\hline $\begin{array}{l}\text { Memory of } \\
\text { ad's content }\end{array}$ & - & - & $50.6 \%$ & $56.7 \%$ & - & - & \\
\hline $\begin{array}{l}\text { Offensive } \\
\text { brand choice }\end{array}$ & $30.4 \%$ & $22.8 \%$ & $33.7 \%$ & $39.1 \%$ & & & \\
\hline
\end{tabular}

To examine further whether exposure to the offensive ad led to a more positive consumer response over time compared to the control ad ( $\mathrm{H} 1)$, we performed a chi square test between ad's condition and brand choice change. While in absolute terms the proportion of respondents choosing the offensive chocolate brand at the end of the study (the long-term 2 measure) is fairly similar between the control and treatment groups (see table 6), a more relevant measure is the change from the baseline to both long-term time points. Looking at the change between the baseline and long-term 1 measure $(-1=$ changed from other brands to the offensive 
chocolate brand, $0=$ no change, $+1=$ changed from the offensive chocolate brand to other brands), we found a marginally significant difference between the control and treatment conditions $\left(\chi^{2}(2)=5.044, p=.08\right)$.

However, when examining the change between the baseline and longterm 2 measure, the effect of ad condition was significant $\left(\chi^{2}(2)=6.67, p<.05\right)$. Among participants who changed their choice to the offensive chocolate brand, $70 \%$ were from the treatment group and only $30 \%$ from the control group. These findings confirm $\mathrm{H} 1$.

To test the moderating role of group membership (H2), we used the Mann-Whitney test to examine how the changes in brand choice over time differed for the two groups (women and men) between the control and treatment conditions. Figure 2 presents the results for each of the three post-exposure time points compared to the baseline for the control and treatment conditions among women and men separately, and in the overall sample. As can be seen, a drop in choosing the offensive chocolate brand is apparent immediately after participants viewed the offensive ad (the short-term measure) among both men and women. However, among women the long-term results show a positive trend which lasts for at least a month.

Further analysis using binomial mixed regression was conducted to predict actual brand choice (the offensive chocolate brand or others) when controlling for random within-subject variation among respondents. The time-since-exposure variable was computed as a dummy variable comprising the two time points that are most relevant for this analysis: baseline and long-term2. The new time-since-exposure variable (baseline vs. longterm2) and ad condition (control vs. treatment) were entered as predictors along with their interaction. The results for this analysis show clearly that the treatment condition yielded higher brand choices than the control condition. See table 7.

\section{Table 7 Choice of the offensive chocolate brand by Time Since Exposure and Ad Condition}

\begin{tabular}{|lll|}
\hline & B & SE \\
Constant & & \\
\hline Time: Long-term2 compared to baseline & $-.13^{\star \star}$ & .04 \\
\hline Treatment compared to control & $-.14^{\star \star}$ & .06 \\
\hline Treatment X long-term2 & $.22^{\star \star \star}$ & .05 \\
\hline AIC & & \\
\hline
\end{tabular}

${ }^{\star} p<.05 ;{ }^{* \star} p<.01 ;{ }^{* \star \star} p<.001$ 
Then, to gain a better understanding of participants' response, we ran binomial regressions separately for each condition. The results are presented in table 8.

\section{Table 8 Choice of offensive chocolate brand by Time since Exposure, Ad Condition, and Gender for Treatment and Control Conditions}

\begin{tabular}{|c|c|c|c|c|c|c|c|c|}
\hline & \multicolumn{4}{|c|}{ Treatment condition } & \multicolumn{4}{|c|}{ Control condition } \\
\hline & \multicolumn{2}{|c|}{$\begin{array}{l}\text { Model 1: } \\
\text { Main effects }\end{array}$} & \multicolumn{2}{|c|}{$\begin{array}{l}\text { Model 2: Main } \\
\text { effects and } \\
\text { interaction }\end{array}$} & \multicolumn{2}{|c|}{$\begin{array}{l}\text { Model 1: } \\
\text { Main effects }\end{array}$} & \multicolumn{2}{|c|}{$\begin{array}{l}\text { Model 2: Main } \\
\text { effects and } \\
\text { interaction }\end{array}$} \\
\hline & B & SE & B & SE & B & SE & B & SE \\
\hline Constant & .27 & .06 & .32 & .06 & .44 & .08 & .43 & .09 \\
\hline $\begin{array}{l}\text { Women compared to } \\
\text { men }\end{array}$ & -.05 & .07 & -.13 & .07 & -.09 & .09 & -.07 & .12 \\
\hline $\begin{array}{l}\text { Time: Long-term2 } \\
\text { compared to baseline }\end{array}$ & $.10 \star \star \star$ & .02 & -.01 & .05 & $-.12^{\star \star \star}$ & .04 & -.10 & .11 \\
\hline Women X Time_long2 & & & $.16^{\star \star \star}$ & .05 & & & -.03 & .11 \\
\hline AIC & 322.22 & & 325.62 & & 206.49 & & 208. & \\
\hline
\end{tabular}

Note: Model 1 presents the main effects of time since exposure and gender; model 2 presents the main effects with their interaction.

${ }^{\star} p<.05 ;{ }^{* \star} p<.01 ; * \star \star x<.001$

From table 8 we can see, overall, a positive main effect of time since exposure only in the treatment condition, confirming the TOP effect. Probing the treatment condition further, adding the gender by time- since-exposure interaction term (Women X Time_long2) was a significant predictor of a preference for the offensive chocolate brand: over the long term, women showed a stronger increase in actual Offensive chocolate brand choices compared to men, demonstrating the trigger TOP effect. Thus, $\mathrm{H} 2$ is confirmed.

To examine whether participants' responses were affected by whether they correctly recalled the name of the brand shown in the ad, we used Fisher's exact tests to test for a link between memory of the brand's name [no (0), yes (1)] and brand choice [others (0), Offensive brand (1)] for each gender within the treatment group. The 
results were insignificant for both men $\left(\chi^{2}(1)=.56, p=.53\right)$ and women $\left(\chi^{2}(1)=.00, p=1.00\right)$. It appears that, as in study 2 , familiarity falls short as an explanation for the positive consumer response. Indeed, as in study 2, the low-power group (women) were less likely to correctly remember the brand's name after 10 days compared to the high-power group $(62.0 \%$ of the women but $77.6 \%$ of the men remembered the brand, $z$ (139) $=1.86, p<.05)$. However, after a month, women remembered the offensive content of the ad more than men did $(56.7 \%$ compared to $37.5 \%, z(139)=-2.17, p<.05$ in a proportion test for independent samples). Examining the relationship between memory of the brand's name and memory of the offensive content in the treatment group yielded a significant result after 10 days (long-term1: $\chi^{2}(1)=4.83, p<.05$ ), but not after a month (long-term2: $\chi^{2}(1)=.29, p=.13$ ).

These findings again suggest that offensiveness in advertising is effective in the long term despite (or because of) its offensive nature. Our fourth study was designed to probe the unconscious processes that may drive these effects.

\section{Study 4: Mediation Model}

Studies 2 and 3 show that low-power individuals (blacks and women, respectively) are more attracted to offensive brands than their high-power counterparts (whites and men). Brands that reflect power are appealing to low-power consumers (Rucker and Galinsky, 2008). Hypothesis 3 thus posited that the influence of an ad's offensiveness on brand choice is mediated by a perception of the brand as powerful and attractive $(\mathrm{H} 3)$. Study 4 aimed to test this hypothesis.

\section{Method}

\section{Participants and Procedure.}

Participants comprised 105 undergraduates $(57.1 \%$ women, Mage $=25.43, S D=1.59)$, recruited via the university subject pool. Participants were asked to complete a questionnaire relating to three well-known brands of beer sold locally. The first was the same brand presented in Study 1, whose marketing strategy is based on the theme "Thank God you're a man." The second brand advertised locally with the slogan "When you have a beer, you have friends." Marketing for the third brand employed the slogan "What's the connection?", followed by the brand's name (in Hebrew, the word for "connection" rhymes with the name of the brand). We anticipated that the first brand would be perceived as most offensive and the third as least offensive. No ads for any of the brands were presented in the survey or in media in the month previous to the experiment, meaning we relied on participants' awareness of the brands and their slogans which represent a long-term response. Participants completed the questionnaires during June 2020

\section{Measures.}


First, participants were asked a simulated choice question. They were asked to choose one beer brand out of three brands. We then asked a series of questions regarding the three brands, presented in random order. The questions assessed brand power, approach tendency, and offensiveness. Before rating offensiveness, respondents were asked to recall the slogans used by each brand. Demographic data were collected last.

Brand power was measured using three items adopted from Anderson and Galinsky's (2006) Generalized Sense of Power Scale. A sample item: "If the brand in the ad were a human, in its relationships with others it would have a great deal of power." Answers were given on a scale from 1 (totally disagree) to 7 (totally agree). Cronbach's alpha for this measure was .87 .

Approach tendency was measured using six items reversed from Becker and Tausch's (2014) avoidance motivation scale. Sample items: "When I drink this beer brand, I feel close to/identify with my opposite gender group." Answers ranged from 1 (not at all) to 7 (very much). Cronbach's alpha for this measure was .96.

Offensiveness was measured using a single question: "Thinking about the brand's advertising slogans, how offensive do you perceive this brand?" Answers were given on a scale from 1 (not offensive at all) to 7 (extremely offensive).

\section{Results and Discussion}

First, as expected, the brand analyzed in study 1 was perceived as most offensive, and the brand marketed under the slogan "What's the connection" was perceived as least offensive. The brand advertised with the slogan "When you have a beer, you have friends" was perceived as moderately offensive. In addition, the brand with the most offensive slogan was rated as having the most brand power, and that with the least offensive slogan was rated as having the least brand power. The descriptive results are presented in table 9 .

\section{Table 9 Descriptive Results for Study 4}




\begin{tabular}{|lllll|}
\hline & $\begin{array}{l}\text { "Thank God you're } \\
\text { a man" (most } \\
\text { offensive) }\end{array}$ & $\begin{array}{l}\text { "When you have } \\
\text { a beer, you have } \\
\text { friends" }\end{array}$ & $\begin{array}{l}\text { "What's the } \\
\text { connection?" } \\
\text { (least offensive) }\end{array}$ & $\begin{array}{l}\text { Differences between } \\
\text { most and least } \\
\text { offensive brands }\end{array}$ \\
\hline Offensiveness & $6.87(1.92)$ & $5.19(1.34)$ & $5.06(1.36)$ & $\mathrm{t}(104)=15.50^{\star}$ \\
\hline $\begin{array}{l}\text { Brand power } \\
\begin{array}{l}\text { Approach } \\
\text { tendency }\end{array}\end{array}$ & $4.77(1.45)$ & $3.17(1.41)$ & $2.24(1.19)$ & $\mathrm{t}(101)=8.55^{\star}$ \\
\hline $\begin{array}{l}\% \\
\text { remembered } \\
\text { the slogan }\end{array}$ & $42.5 \%$ & $2.28(1.29)$ & $1.97(1.21)$ & $\mathrm{t}(102)=8.64^{\star}$ \\
\hline \begin{tabular}{l}
$\%$ choice \\
\hline
\end{tabular} & $12.3 \%$ & $31.9 \%$ & $\chi^{2}(1)=2.537, \mathrm{n} . \mathrm{s}$ \\
\hline
\end{tabular}

$* p<.001$

Comparable percentages of men and women remembered the slogan of the least offensive brand $(35.6 \%$ of the men compared with $28.3 \%$ of the women: $\left.\chi^{2}(1)=.62, p=.28\right)$. However, this difference was significant and substantial for the most offensive brand $\left(63.6 \%\right.$ of the men compared with $29.3 \%$ of the women: $\chi^{2}(1)=$ $11.9, p<.001)$. This again suggests unconscious processes may be at work.

We next checked for gender differences in approach tendency toward both brands. Differences were observed only in the gender-offensive brand, where women found the brand more appealing than men $(\mathrm{t}(101)=-1.68$, $p<.05)$. No gender differences were found in approach tendency to the less offensive brand $(\mathrm{t}(101)=-.085, p$ $=.93$ ). Mixed regression was used to control for the within-subject factor, given that all participants provided approach tendency responses for all three brands. A mixed regression predicting tendency to approach using offensiveness (least or most offensive) and gender as predictors yielded a significant interaction $(F(1)=4.29$, $p<.05$; see figure 3 ). These results confirm $\mathrm{H} 2$ (the trigger TOP effect).

To probe these findings further, we ran a three-path mediation model for the most and least offensive brands separately using AMOS, The DV of the three-path mediation analysis was coded as a dummy variable comparing between 1-the brand examined in the statistical analysis (most/least offensive), 0 - the other brands. See figure 4 and table 9 for the results.

\section{Table 10 Mediation Model Path Coefficients and Indirect Effects (Study 4)}




\begin{tabular}{|c|c|c|c|c|c|c|}
\hline \multicolumn{5}{|c|}{ Path coefficient } & \multicolumn{2}{|c|}{ Indirect effect } \\
\hline & & $\begin{array}{l}\text { To brand } \\
\text { choice (BC) }\end{array}$ & $\begin{array}{l}\text { To brand } \\
\text { power (BP) }\end{array}$ & $\begin{array}{l}\text { To brand } \\
\text { attraction } \\
\text { (BA) }\end{array}$ & Estimate & $\begin{array}{l}\text { Bias- } \\
\text { corrected } \\
95 \% \mathrm{Cl}\end{array}$ \\
\hline \multirow[t]{7}{*}{$\begin{array}{l}\text { Most } \\
\text { offensive } \\
\text { brand }\end{array}$} & $\begin{array}{l}\text { Ad's } \\
\text { offensiveness } \\
\text { (AO) }\end{array}$ & $-.04(.02)$ & $.24^{\star \star \star}(.07)$ & $-.07 \star \star \star ~(.07)$ & & \\
\hline & Brand power & $.007(.03)$ & & $.33^{\star \star \star}(.10)$ & & \\
\hline & $\begin{array}{l}\text { Brand } \\
\text { attraction }\end{array}$ & $.09 \star *(.03)$ & & & & \\
\hline & Total & & & & $-.035(.01)$ & $-.02, .02$ \\
\hline & $\mathrm{AO}->\mathrm{BA}->\mathrm{BC}$ & & & & $\begin{array}{l}-.006 \\
(.009)\end{array}$ & $\begin{array}{l}-.027 \\
.006\end{array}$ \\
\hline & $\mathrm{AO}->\mathrm{BP}->\mathrm{BC}$ & & & & $\begin{array}{l}.002 \\
(.007)\end{array}$ & $\begin{array}{l}-.011 \\
.015\end{array}$ \\
\hline & $\begin{array}{l}\mathrm{AO}->\mathrm{BP}->\mathrm{BA}- \\
>\mathrm{BC}\end{array}$ & & & & $\begin{array}{l}.007^{\star \star} \\
(.005)\end{array}$ & $.001, .022$ \\
\hline \multirow[t]{7}{*}{$\begin{array}{l}\text { Least } \\
\text { offensive } \\
\text { brand }\end{array}$} & $\begin{array}{l}\text { Ad's } \\
\text { offensiveness } \\
\text { (AO) }\end{array}$ & $-.008(.007)$ & .15(.09) & $.08(.08)$ & & \\
\hline & Brand power & $-.001(.008)$ & & 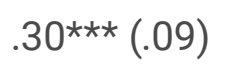 & & \\
\hline & $\begin{array}{l}\text { Brand } \\
\text { attraction }\end{array}$ & $.02(.009)$ & & & & \\
\hline & Total & & & & $\begin{array}{l}-.005 \\
(.004)\end{array}$ & $-.011, .000$ \\
\hline & $\mathrm{AO}->\mathrm{BA}->\mathrm{BC}$ & & & & $.002(.003)$ & $\begin{array}{l}-.003 \\
.009\end{array}$ \\
\hline & $\mathrm{AO}->\mathrm{BP}->\mathrm{BC}$ & & & & $.000(.001)$ & $\begin{array}{l}-.002 \\
.001\end{array}$ \\
\hline & $\begin{array}{l}\mathrm{AO}->\mathrm{BP}->\mathrm{BA}- \\
>\mathrm{BC}\end{array}$ & & & & $.001(.001)$ & $\begin{array}{l}-.001 \\
.004\end{array}$ \\
\hline
\end{tabular}

Note. $+p<.1 ;{ }^{\star} p<.05 ;{ }^{* \star} p<.01 ;{ }^{* \star \star} p<.001 ;$ boot $=5000$.

As can be seen in Table 10, full mediation appears only when the brand's advertising strategy is offensive: the more offensive the brand's slogan or ads, the more powerful the brand, the greater respondents' attraction to it, and the more likely respondents are to choose that brand. This overall effect on the population as a whole is driven by a mediation effect which is apparent only among women. The estimate for the path AO->BP->BA- 
>BC for women is .01 (.01), 95\%, [.000, .042]. However, this path was insignificant for men: .002(.004), 95\%, $[-.002, .017]$. These results confirm H3.

\section{General Discussion}

Offensive ads are known to lead to an immediate decline in purchase intentions and actual brand choice (e.g. Rojas-Mendez, Davies, and Madran 2009; Van Hellemont and Van den Bulck 2012). However, the use of such ads continues to increase, leading to a discrepancy between the literature and practice. We suggest that this discrepancy can be resolved by adding a time dimension to power-approach theory, whereby powerful objects, people or brands are attractive to others (Keltner et al. 2003). In this study, we show an increase in purchase intentions and brand choice among low-power groups, but only after time has passed following exposure to an offensive ad. We posit that members of these groups are subconsciously attracted to the power conveyed by the offensive nature of the ad.

More precisely, in four studies, we find a greater positive change between the short- and long-term consumer response among participants exposed to an offensive brand compared to a non-offensive brand. We term this the time-offense paradox (TOP). Furthermore, this change is larger among low-power groups in society, which are subject to discrimination, compared to the high-power group, creating what we call the 'trigger TOP' effect. We find these effects in both field studies (studies 1a and 1b) and online experiments (studies 2 and 3). The mechanism explaining the positive consumer response to offensive ads over the long term is shown to be a perception of power in the offensive brand that attracts offended consumers, elevating brand choice (study 4). Finally, we ruled out "buzz" or familiarity explanations for this elevated consumer response, as consumer response was no higher among participants who correctly remembered the brand seen in the ad 10 days or a month later, compared with those who did not remember the brand.

\section{Theoretical Contributions}

The main contribution of this research is that we resolve the discrepancy between the immediate negative response to offensive ads seen in the literature and increasing use of such ads in practice. We do this by adding the time dimension to power-approach theory. Specifically, we show that offensive ads trigger an immediate negative response, but an overall positive recovery effect ten days following exposure to the ad (to the level of neutral ads), and an even more positive change in consumer response over the long term, a month following exposure. This study is the first research to demonstrate such a changing consumer reaction over time to offensive ads. Further, we show that this positive increase in actual brand choice is driven largely by processes among low-power groups (the trigger TOP effect). Finally, we expand our understanding of this effect by highlighting power-signaling by offensive ads, and its attractive force among low-power populations, as the mechanism driving our observed effects. As such, the trigger TOP is aligned with the predictions of power-approach theory, and also with compensatory consumption theory, which suggests that especially powerless individuals will want to purchase brands associated with high-power groups as a way to (re)gain power (Mandel et al. 2017; Rucker and Galinsky 2008; Ward and Dahl 2014;).

Page 29/38 
Kyres (2016) illustrated this process in an essay called "I too want to loosen up like a man." Writing about a television ad run by the same brand of beer we examined in studies 1 and 4 , she explained: "When advertisers are laughing at women, I'd rather be on the men's side and feel I am a cool and easy-going woman" (translation from Hebrew by the present authors). While Kyres purports to dislike the ad, by drinking the brand's beer she can distance herself from the stereotypical and silly girls who are portrayed in the commercial.

\section{Limitations}

First, the field study might be affected by numerous factors that are not controlled for, such as sampling bias, dates of data collections, dates of advertisement airing, etc. This is a known limitation of field studies. The lab studies complement the field study and control for many of these variables. Second, current studies do not include the daily actual choice. This would examine whether there is a decrease in actual choice in the short term, and if so, it's duration. Third, the gender experiment had an attrition bias: those who felt less offended dropped out for the later stages of the study. This attrition did not occur in the race experiment, that showed the same trend of results as the gender experiment.

\section{Future Research}

Our findings also highlight fertile directions for future studies. First, the ethical aspects of using offensive ads should be given more attention in future research. Though we show a long-term positive effect of offensive ads on purchase intentions and brand choice, such ads may also cause social harm. Images in the media can have a psychological effect on the individual by shaping self-conceptions, by supplying ideals that may be internalized (e.g., white is purity), by emphasizing the values or power of a particular social group compared with other groups, and by reinforcing negative social stereotypes (Crockett, Grier, and Williams 2003; Ward 2004). Future research could examine ways to reduce the use of such ads even though they elevate sales-for example, using action research to trial small-scale educational interventions aimed at making consumers more aware of the manipulative nature of advertising. For example, this can be done by manipulating power among discriminated groups, in order to give the discriminated groups a sense of power that will satisfy the need of power and reduce the need to conceive power by purchasing an offensive but powerful brand (see for example SimanTov-Nachlieli, Shnabel and Halabi (2016) who show that manipulating power affirms discriminated groups' feeling of agency and promotes prosocial tendencies).

The effect of such interventions on consumers' response could then be examined over the short and long terms.

Second, in this research, we showed offensive ads are more effective than neutral ads that only display the product, over a month since exposure to the ad. Future research needs to examine whether positive ads, 
which emphasize a desirable aspect of the product can be more effective or at least as effective as offensive ads. This is needed in order to offset the apparent TOP that might encourage firms to use offensive ads.

Third, our research suggests that consumer behavior is driven by unconscious processes. Future research should examine the implicit tendency to approach high-power brands. For example, implicit association tests can be used to measure the strength of associations between concepts (e.g., offensive brand name) and evaluations (e.g., white people). Other studies could use tools such as EEG to measure activation in different areas of the brain when a stimulus or stimuli are presented (e.g., Offensive brand name, a white person). Such studies could clarify the conditions under which individuals demonstrate avoidance or approach motivations and help elucidate unconscious attraction to the higher power group and the brand.

\section{Implications}

Beyond its theoretical contributions, this research suggests that societies should consider the potential value of legislation limiting the use of offensive ads. Many societies have already established regulations prohibiting the use of gender stereotypes in advertising. For example, a new rule banning the use of harmful gender stereotypes in ads was enacted in June, 2019, in the UK (Waterson 2018). The establishment and implementation of such regulatory policies is fraught, given the difficulty of defining specific criteria for exclusion, and determining what sorts of penalties to impose on those who break the rules. Moreover, other groups who suffer stereotyping and discrimination, such as ethnic or national minorities, may deserve similar protections, raising further questions as to what criteria reasonably constitute harmful stereotypes in many different cases. Resolving such questions is not easy. But such regulation may promote a better and more just society for all individuals.

In conclusion, our research shows the efficacy of offensive ads in the long term, and specifically on the consumer response of low-power groups. By adding the time dimension to power-approach theory and by highlighting the mechanism explaining the positive consumer response to offensive ads in the long term, we help resolve the discrepancy between the negative immediate consumer response to offensive ads found in the literature, and the continuing use of such ads by brands.

\section{Declarations}

\section{Competing interests:}

The authors declare no competing interests..

\section{References}

1. Alwitt, Linda F., \& Paul R. Prabhaker. (1994) "Identifying Who Dislikes Television Advertising: Not by Demographics Alone," Journal of Advertising Research, 34 (6), 17-30. 
2. Anderson, C. and A. D. Galinsky (2006), “Power, Optimism, and Risk-taking,” European Journal of Social Psychology, 36(4), 511-36.

3. Astor, Maggie (2017), “Dove Drops Ad After it Draws Criticism for Being Racist,” The New York Times, https://www.nytimes.com/2017/10/08/business/dove-ad-racist.html (accessed February 10, 2020).

4. Beck, J. T., Rahinel, R., \& Bleier, A. (2020), “Company Worth Keeping: Personal Control and Preferences for Brand Leaders," Journal of Consumer Research, 46(5), 871-886.

5. Becker, J. C. and N. Tausch (2014), "When Group Memberships Are Negative: The Concept, Measurement, and Behavioral Implications of Psychological Disidentification," Self and Identity, 13(3), 294-321.

6. Berger, J., B. P. Cohen, and M. Zelditch, Jr. (1972), “Status Characteristics and Social Interaction," American Sociological Review, 37 (3), 241-55.

7. Bond, M. H., Wan, K. C., Leung, K., and Giacalone, R. A. (1985), “How are responses to verbal insult related to cultural collectivism and power distance?", Journal of Cross-Cultural Psychology, 16(1), 111-127.

8. Bracha, S., A. E. Williams, and Bracha (2004), “Does 'Fight or Fight' Need Updating?” Psychosomatics, 45 (5), 448-49.

9. Calkins, Tim and D. Derek Rucker (2016), “Why GoDaddy's Offensive Super Bowl Ads Worked,” Fortune, http://fortune.com/2016/02/04/godaddy-super-bowl-50/ (accessed February 10, 2020).

10. Chan, K., L. Li, S. Diehl, and R. Terluter (2007), “Consumers' Response to Offensive Advertising: A Cross Cultural Study," International Marketing Review, 24 (5), 606-28.

11. Chen, Z. and J. Berger (2013), “When, Why, and How Controversy Causes Conversation,” Journal of Consumer Research, 40 (3), 580-93.

12. Clark, Amy (2007), "Snickers 'Kiss' Super Bowl Ad Was Pulled," Money Watch, https://www.cbsnews.com/news/snickers-kiss-super-bowl-ad-pulled/ (accessed February 10, 2020).

13. Cohen-Eliya, Moshe and Y. Hammer (2004), "Advertisements, Stereotypes, and Freedom of Expression,” Journal of Social Philosophy, 35 (2), 165-87.

14. Coleman, N. V., Williams, P., \& Morales, A. C. (2019). Identity threats, compensatory consumption, and working memory capacity: How feeling threatened leads to heightened evaluations of identity- relevant products. Journal of Consumer Research, 46(1), 99-118.

15. Crockett, David, Sonya A. Grier, and Jacqueline A. Williams (2003), “Coping with Marketplace Discrimination: An Exploration of the Experiences of Black Men," Academy of Marketing Science Review, $4(7), 1-21$.

16. Crosier, Keith and B. Zafer Erdogan. (2001), "Advertising Complainants: Who and Where Are They?" Journal of Marketing Communications, 7 (2), 109-20.

17. European Advertising Standards Alliance (EASA) (2017). Statistics, http://www.easa alliance.org/products-services/publications/statistics (accessed February 10, 2020).

18. Fam, Kim Shyan and David S. Waller (2003), "Advertising Controversial Products in the Asia Pacific: What Makes Them Offensive?" Journal of Business Ethics, 48 (3), 237-50.

19. Fiske, T. Susan (1993), “Controlling Other People: The Impact of Power on Stereotyping," American Psychologist, 48 (6), 621-28. 
20. Fleiss, J. L. (2011), Design and Analysis of Clinical Experiments (Vol. 73), New York, NY: Wiley.

21. Ford, J. B., LaTour, M. S., \& Honeycutt, E. D. (1997), “An examination of the cross-cultural female response to offensive sex role portrayals in advertising", International Marketing Review, 14 (6), $409-423$.

22. Friedmann, E., \& Brueller, D. (2018), “Is stereotypical gender targeting effective for increasing service choice?" Journal of Retailing and Consumer Services, 44, 35-44.

23. Furnham, Adrian and Alixe Lay (2019), "The Universality of the Portrayal of Gender in Television Advertisements: A Review of the Studies This Century," Psychology of Popular Media Culture, 8 (2), 109124.

24. Haaretz (2015), “Goldstar Beer Ad Slammed as Sexist,” https://www.haaretz.com/goldstar-beer-adslammed-as-sexist-1.5375995 (accessed February 10, 2020).

25. Hall, Emma (2016), “Coca-Cola Pulls Offensive Sprite Ad in Ireland," Ad Age http://adage.com/article/global-news/coca-cola-pulls-sexist sprite-ad-ireland/305323/ (accessed February 10, 2020).

26. Huhmann, B. A. and B. Mott-Stenerson (2008), “Controversial Advertisement Executions and Involvement on Elaborative Processing and Comprehension," Journal of Marketing Communications, 14 (4), 293313.

27. Idiens, Miranda Emilia (2018), “A Comprehensive Timeline of Every Offensive Comment Stefano Gabbana Has Ever Made," Fashion, https://fashionmagazine.com/style/stefano-gabbana-offensivetimeline/ (accessed February 10, 2020).

28. Johnson, Aaron T., Kimberly A. Neuendorf, and Paul D. Skalski (2012), “Joking with an Agenda: Racial Disparagement Humor Appreciation and Social Power Value Motivation," Intercultural Communication Interest Group of the Central States Communication Association, Cleveland, $\mathrm{OH}$.

29. Klimin, Anastasii and Dmitrii Tikhonov (2016), “Perception of Offensive Advertising: Cross Cultural Peculiarities," Paper presented at the Cross-Cultural Business Conference.

30. Kyres, Vita (2016), "I Too Want to Loosen Up Like a Man,” Mako, https://www.mako.co.il/womenmagazine/Article-21a410577f70651006.htm (accessed February 10, 2020).

31. London, Moran (2015), "Goldstar is Out of the Closet," Calcalist, https://www.calcalist.co.il/consumer/articles/0,7340,L-3664080,00.html (accessed February 10, 2020).

32. Liu, P. J., Lamberton, C., Bettman, J. R., \& Fitzsimons, G. J. (2019), “Delicate Snowflakes and Broken Bonds: A Conceptualization of Consumption-Based Offense," Journal of Consumer Research, 45(6), 1164-1193.

33. Lukyanova, Tanya (2016), "Shockingly Offensive Ads that Came Out Way Too Recently," Cracked, https://www.cracked.com/article_24122_6-insane-messages-in-completely-banalcommercials.htm (accessed February 10, 2020).

34. Madni, Abdul Rehman, Norsiah Abdul Hamid, and Sabrina Mohd Rashid (2016), "Influence of Controversial Advertisement on Consumer Behavior," The Journal of Commerce, 8 (2), 14-24.

35. MacKenzie, Scott B., Richard J. Lutz., \& George E. Belch. (1986), “The Role of Attitude

Toward the Ad as a 
Mediator of Advertising Effectiveness: A Test of Competing Explanations," Journal of Marketing Research, 23 (2), 130-143.

36. Magee, Joe C. and Adam D. Galinsky (2008), "Social Hierarchy: The Self-Reinforcing Nature of Power and Status," Academy of Management Annals, 2 (1), 351-98.

37. Mandel, N., D. D. Rucker, J. Levav, and A. D. Galinsky (2017), "The Compensatory Consumer Behavior Model: How Self-discrepancies Drive Consumer Behavior," Journal of Consumer Psychology, 27(1), 13346.

38. Matthes, J., M. Prieler, and K. Adam (2016), "Gender-role Portrayals in Television Advertising across the Globe," Sex Roles, 75 (7-8), 314-27.

39. Mertes, Alyssa (2019), "12 Offensive Advertisements Your Business Can Learn From," Quality Logo Products blog, https://www.qualitylogoproducts.com/blog/12-offensive-advertisements/ (accessed February 10, 2020).

40. Piedfort, M. (2019), "12 Bad Ads and Marketing Failures to Learn What Not to Do," Workzone, https://www.workzone.com/blog/bad-ads/ (accessed February 10, 2020).

41. Prendergast, Gerard, Benny Ho, and lan Phau (2002), "A Hong Kong View of Offensive Advertising," Journal of Marketing Communications, 8 (3), 165-77.

42. Rahim, Lucy (2017), "12 of the Most Controversial Fast Food Adverts of All Time," The Telegraph, https://www.telegraph.co.uk/food-and- rink/features/11-controversial-fast-food-advertstime/ (accessed February 10, 2020).

43. Ritzer, George and Jeffrey Stepinisky (2007), Contemporary Sociological Theory and its Classical Roots: The Basics, Boston: McGraw-Hill.

44. Rojas-Méndez, José I., Gary Davies, and Canan Madran (2009), "Universal Differences in Advertising Avoidance Behavior: A Cross-Cultural Study," Journal of Business Research, 62 (10), 947-54.

45. Rucker, Derek D. and Adam D. Galinsky (2008), "Desire to Acquire: Powerlessness and Compensatory Consumption," Journal of Consumer Research, 35 (2), 257-67.

46. Sengupta, J. and D. W. Dahl (2008), "Gender-related Reactions to Gratuitous Sex Appeals in Advertising," Journal of Consumer Psychology, 18, 62-78.

47. Shandrow, Kim Lachance (2016), "11 Disturbingly Offensive Ads That Landed Big Brands in Trouble," Entrepreneur Europe, https://www.entrepreneur.com/slideshow/280504\# (accessed June 30, 2020).

48. SimanTov-Nachlieli, I., Shnabel, N., \& Halabi, S. (2016), "The power to be moral: Affirming Israelis' and Palestinians' agency promotes prosocial tendencies across group boundaries, "Journal of Social Issues, 72(3), 566-583.

49. Sue, D. W. (2010), "Microaggressions, Marginality, and Oppression: An Introduction," in Microaggressions and Marginality: Manifestation, Dynamics, and Impact, ed. D. W. Sue, Hoboken, NJ: Wiley, 3-24.

50. Szymanski, Dawn M. and Kimberly F. Balsam (2011), "Insidious Trauma: Examining the Relationship Between Heterosexism and Lesbians' PTSD Symptoms," Traumatology, 17 (2), 4-13.

51. Van Hellemont, Corine and Hilde Van den Bulck (2012), "Impacts of Advertisements that Are Unfriendly to Women and Men," International Journal of Advertising, 31 (3), 623-56. 
52. Wade, L. (2014), "Snickers Mocks the Idea that Men Can Respect Women," The Society Page, https://thesocietypages.org/socimages/2014/12/27/snickers-mocks-the-idea-that-men-can-respectwomen/ (accessed February 10, 2020).

53. Waller, David S. (2004), "What Factors Make Controversial Advertising Offensive? A Preliminary Study," paper presented at the Australia/New Zealand Communication Association (ANZCA) Conference, Sydney.

54. Waller, David S., S. Deshpande, and B. Zafer Erdogan (2013), "Offensiveness of Advertising with Violent Image Appeal: A Cross-Cultural Study," Journal of Promotion Management, 19 (4), 400-17.

55. Ward, L. Monique (2004), "Wading Through the Stereotypes: Positive and Negative Associations Between Media Use and Black Adolescents' Conceptions of Self," Developmental Psychology, 40 (2), 284- 293.

56. Ward, M. K. and D. W. Dahl (2014), "Should the Devil Sell Prada? Retail Rejection Increases Aspiring Consumers' Desire for the Brand," Journal of Consumer Research, 41 (3), 590-609.

57. Waterson, J. (2018), "UK Advertising Watchdog to Crack Down on Sexist Stereotypes," The Guardian, https://www.theguardian.com/media/2018/dec/14/uk-advertising-watchdog-to-crack down-on-sexiststereotypers (accessed February 10, 2020).

58. Wisse, B. and E. Sleebos, E. (2016), “When the Dark Ones Gain Power: Perceived Position Power Strengthens the Effect of Supervisor Machiavellianism on Abusive Supervision in Work Teams," Personality and Individual Differences, 99, 122-26.

59. Yzerbyt, V. Y., M. Dumont, D. Wigboldus, and E. Gordijn (2003), "I Feel for Us: The Impact of Categorization and Identification on Emotions and Action Tendencies," British Journal of Social Psychology, 42 (4), 533-49.

60. Zeigler-Hill, Virgil (2007), "Contingent Self-Esteem and Race: Implications for the Black Self Esteem Advantage," Journal of Black Psychology, 33 (1), 51-74.

\section{Figures}




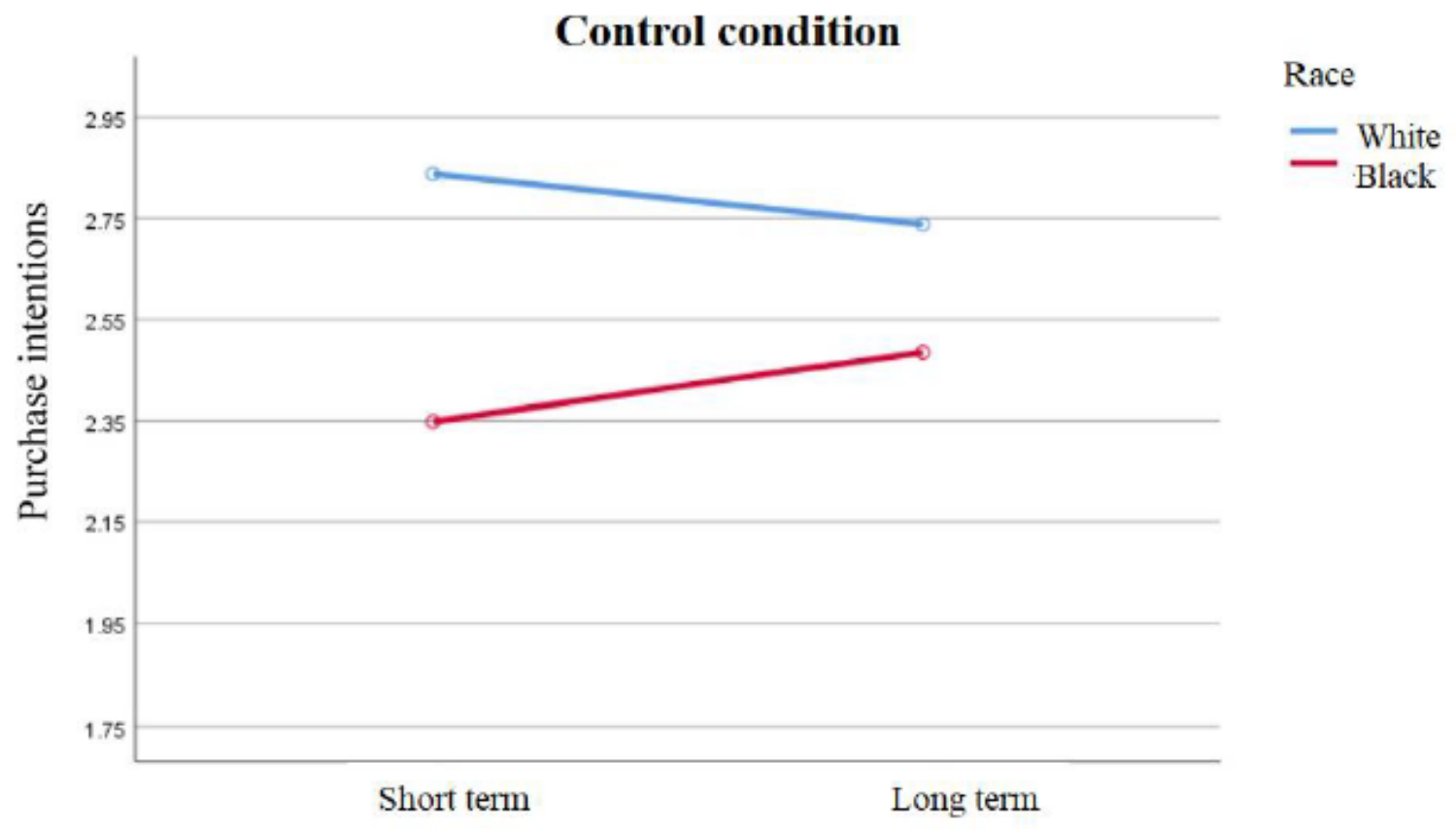

Treatment condition

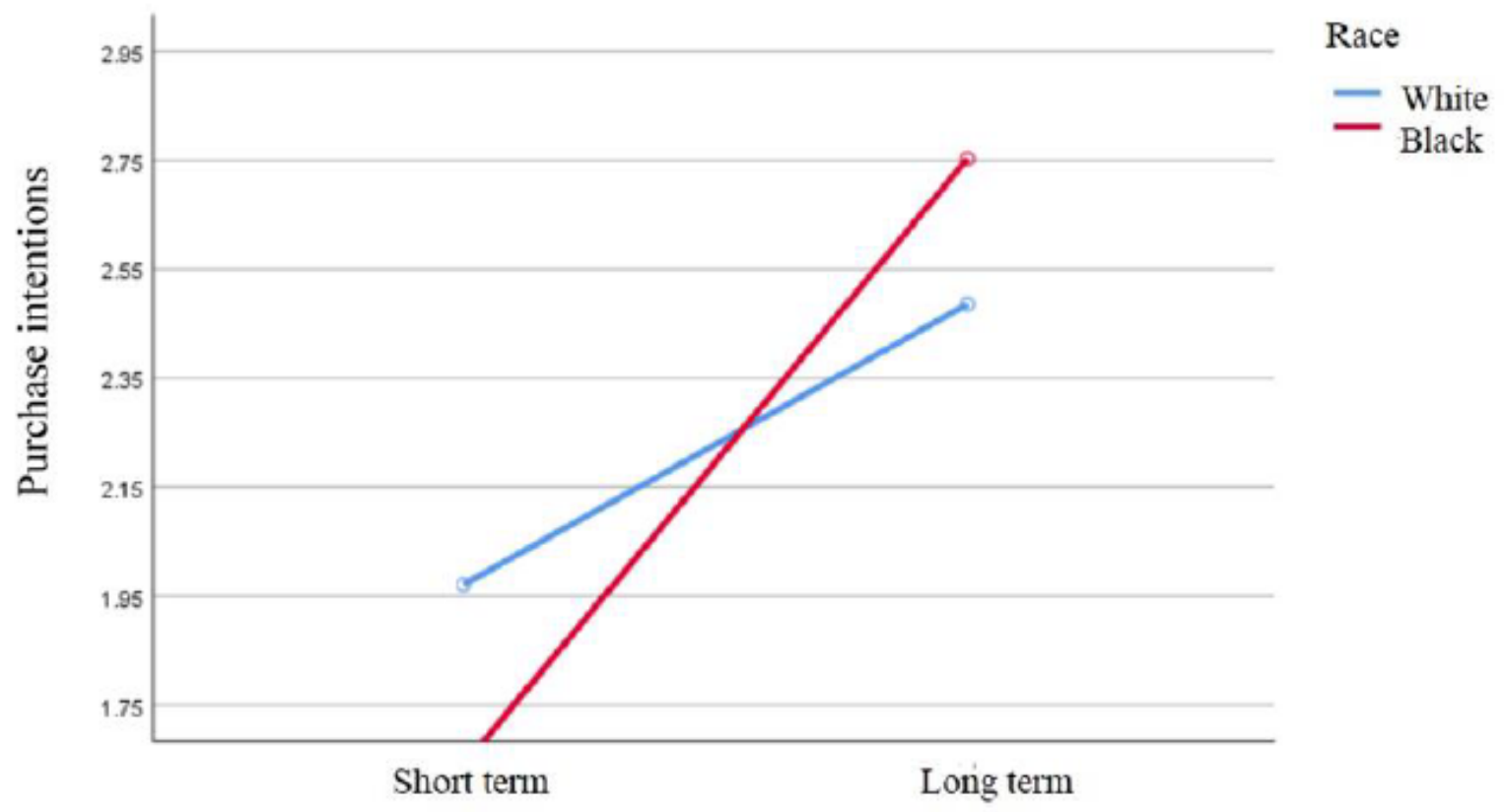

Figure 1

PURCHASE INTENTIONS BY RACE AND TIME SINCE EXPOSURE FOR CONTROL AND TREATMENT CONDITIONS 


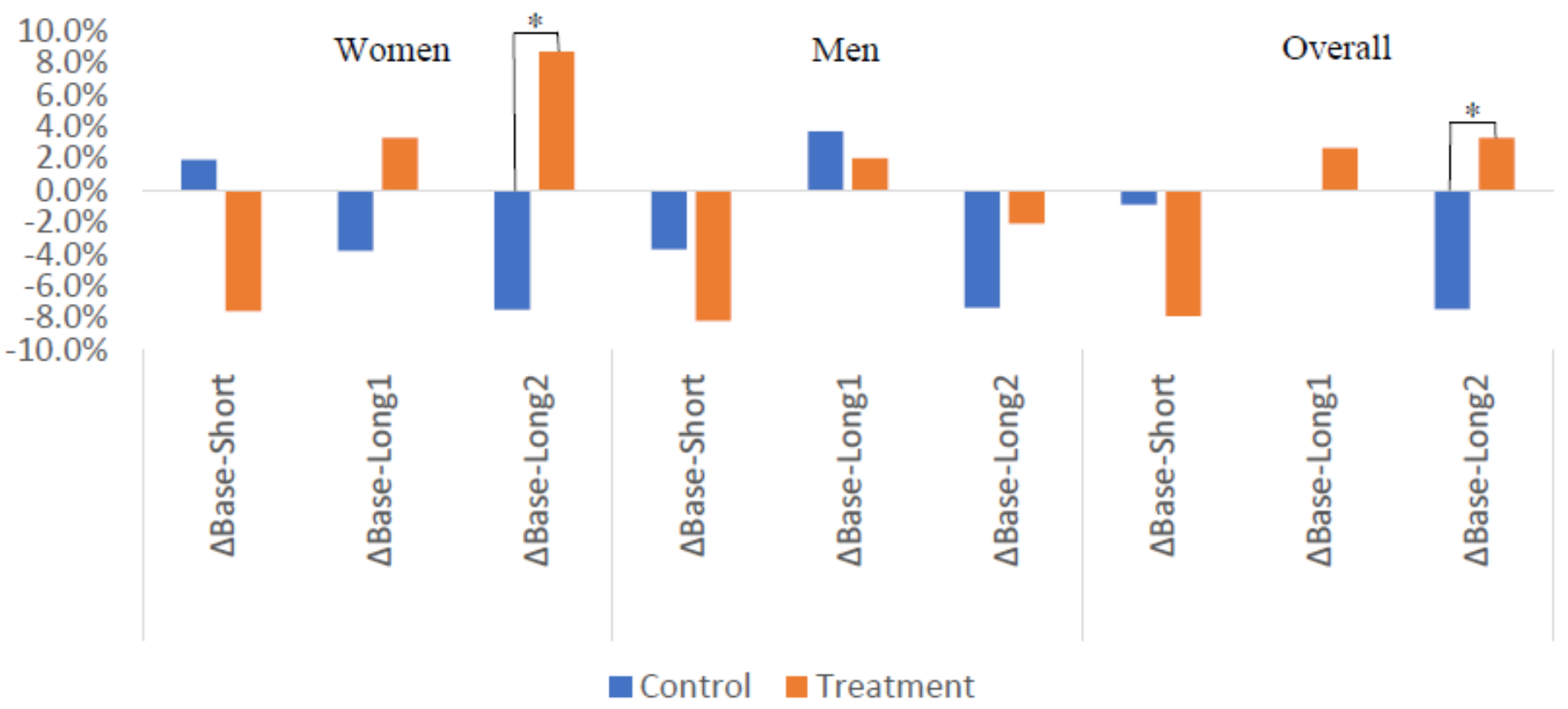

${ }^{*} \mathrm{p}<.05$

\section{Figure 2}

ACTUAL CHANGE IN OFFENSIVE BRAND CHOICE (FROM OTHER TO) BETWEEN SHORT AND LONG TERMS COMPARED TO BASELINE FOR CONTROL VS TREATMENT CONDITIONS, AMONG WOMEN AND MEN AND OVERALL

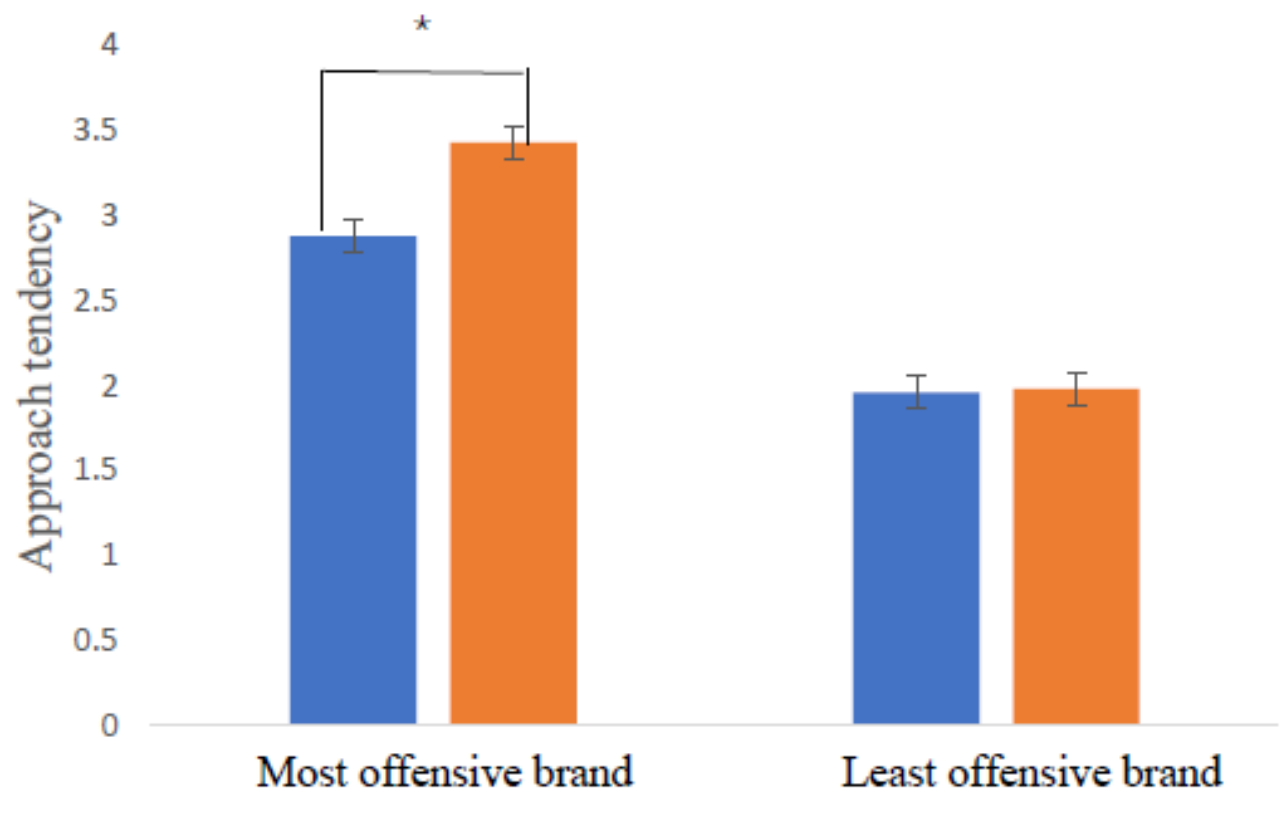

$* \mathrm{p}<.05$ 
Figure 3

GENDER DIFFERENCES IN APPROACH TO THE LEAST OFFENSIVE VS. MOST OFFENSIVE BRAND (STUDY 4)
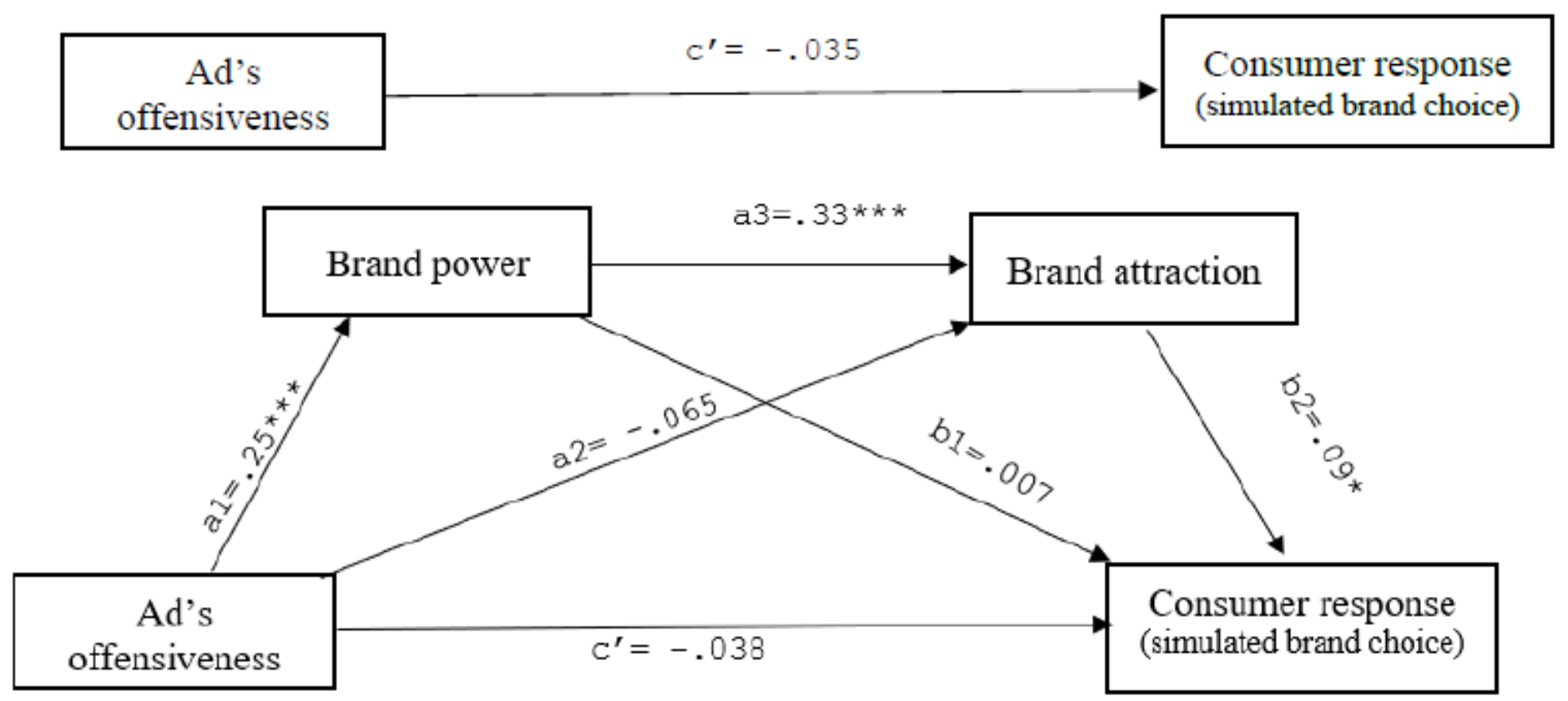

Figure 4

FULL MEDIATION MODEL RESULTS FOR MOST-OFFENSIVE BRAND (STUDY 4) 